\title{
LOS ARTÍCULOS 9.2 Y 9.3 DEL CÓDIGO CIVIL Y EL RÉGIMEN ECONÓMICO MATRIMONIAL EN DERECHO INTERNACIONAL PRIVADO ESPAÑOL. VALORES, MÉTODOS Y TÉCNICAS
}

\author{
ARTICLES 9.2 AND 9.3 OF THE CIVIL CODE \\ AND MATRIMONIAL PROPERTY REGIMES IN SPANISH \\ PRIVATE INTERNATIONAL LAW. \\ VALUES, METHODS AND TECHNIQUES
}

\author{
Alfonso-Luis Calvo Caravaca \\ Catedrático de Derecho internacional privado \\ Universidad Carlos III de Madrid \\ Vocal Permanente de la Comisión General de Codificación \\ ORCID ID: 0000-0003-2236-4641 \\ JaVier CARrascosa GonzÁlez \\ Catedrático de Derecho internacional privado \\ Universidad de Murcia \\ ORCID ID: 0000-0002-0347-7985
}

Recibido: 21.05.2020 / Aceptado: 08.06.2020

DOI: https://doi.org/https://doi.org/10.20318/cdt.2020.5608

\begin{abstract}
Resumen: El presente estudio lleva a cabo un análisis de los arts. 9.2 y 9.2 del Código civil y de la relación entre ambos preceptos. Se pone de relieve que el art. 9.2 CC es la norma central del sistema, una norma que se ha quedado anticuada al otorgar demasiado espacio a la Ley personal y no admitir una elección clara y simple de la Ley aplicable a los efectos del matrimonio y de la ley aplicable a los contratos matrimoniales. Ambos preceptos están en pleno vigor y se aplican a los matrimonios celebrados antes del 29 de enero de 2019. Este trabajo sostiene que el art. $9.3 \mathrm{CC}$ debe ser entendido como una norma que aumenta las posibilidades de validez de las capitulaciones matrimoniales en casos internacionales.
\end{abstract}

Palabras clave: matrimonio, efectos del matrimonio, contratos matrimoniales, cláusula salvatoria.

Abstract: This study carries analyzes Articles 9.2 and 9.2 of the Spanish Civil Code and the relationship between both legal provisions. It is highlighted that art. $9.2 \mathrm{CC}$ is the central rule of the system. It is a legal provision norm that has become outdated by giving too much space to the personal Law and not admitting a clear and simple choice of the Law applicable to the effects of marriage and the law applicable to marriage contracts. Both Articles are in full force and are to be applied to marriages celebrated before January 29, 2019. This work maintains that art. $9.3 \mathrm{CC}$ must be understood as a rule that increases the possibilities of validity of marriage contracts in cases involving foreign elements.

Keywords: marriage, effects of marriage, marriage contracts, saving clause. 
Sumario: I. Introducción. Reglamento 2016/1003 y artículos 9.2 y 9.3 CC. II. Ley aplicable a la celebración del matrimonio y Ley aplicable a los efectos del matrimonio. 1. Matrimonium in fieri y matrimonium in facto esse. Efectos internos y efectos externos del matrimonio. 2. Efectos personales y efectos patrimoniales derivados del matrimonio. A) Efectos personales del matrimonio. B) Efectos patrimoniales del matrimonio. Los distintos regímenes económicos matrimoniales en el mundo. III. Cuestiones de Derecho transitorio. El ocaso de la Ley nacional del marido. IV. Ley aplicable a los efectos del matrimonio en Derecho internacional privado español. Los artículos 9.2 y 9.3 del Código Civil. 1. Posición de los arts. 9.2 y 9.3 en el sistema. 2. La norma central. El artículo 9.2 CC. A) Caracteres generales del art. 9.2 CC. a) Unidad de la Ley aplicable a los efectos del matrimonio. b) Conexiones en cascada. c) Puntos de conexión constitucionalizados. d) Eliminación del conflicto móvil. B) Los puntos de conexión recogidos el en art. 9.2 CC. a) Nacionalidad común de los cónyuges. i) El vértigo de la Ley nacional ataca de nuevo. ii) Reenvío y Ley nacional común de los cónyuges. iii) Conflicto móvil y nacionalidad de los cónyuges. iv) Apatridia y nacionalidad indeterminada de los cónyuges. v) Efectos del matrimonio entre españoles en casos internacionales e interregionales. b) Elección de Ley por los cónyuges. (i) Condiciones para una válida elección de Ley. (ii) Ventajas prácticas de una elección de Ley en el contexto del art. 9.2 CC. c) Residencia habitual común. d) Lugar de celebración del matrimonio. C) Ámbito de la Ley designada por el art. 9.2 CC. 3. Ley aplicable a los pactos y capitulaciones matrimoniales. A) Reglas generales. B) El art. 9.3 CC: cláusula salvatoria de la validez de los pactos y capitulaciones matrimoniales. C) Caracteres del art. $9.3 \mathrm{CC}$. a) Acuerdos interconyugales cubiertos por el precepto. b) Puntos de conexión alternativos y autonomía conflictual oculta. c) Capitulaciones redactadas con arreglo a varias leyes estatales (dépeçage). d) Cambio del contenido de los pactos o capitulaciones matrimoniales. e) Reenvío y art. 9.3 CC. f) Pactos de elección de Ley contenidos en capitulaciones matrimoniales. g) Pactos de elección de Ley aplicable al régimen económico matrimonial. D) Ámbito de la Ley designada por el art. 9.3 CC. a) Cuestiones reguladas por la Ley a la que remite el art. 9.3 CC. b) Ley aplicable a la interpretación de las capitulaciones matrimoniales y la liquidación del régimen económico matrimonial y art. 9.3 CC. c) Capacidad para otorgar pactos o capitulaciones matrimoniales. d) Consentimiento para otorgar pactos o capitulaciones matrimoniales. e) Ley aplicable a la forma de los pactos o capitulaciones matrimoniales. V. Reflexiones finales

\section{Introducción. Reglamento 2016/1003 y artículos 9.2 y 9.3 CC.}

1. En la actualidad y en los supuestos con elementos extranjeros el régimen económico matrimonial se rige, en la actualidad, para todos los Estados miembros de la Unión Europea que participan en el mismo, por la Ley designada a través de las normas de conflicto contenidas en el Reglamento 2016/1103 del Consejo de 24 junio 2016 [regímenes económicos matrimoniales] ${ }^{1}$. Este Reglamento se aplica íntegramente, en general, a matrimonios celebrados tras el día 29 enero $2019^{2}$. En tales casos, observa M. ANDRAE, visto el amplio ámbito de aplicación material del Reglamento, quedarán desactivadas las normas de conflicto de los Estados miembros que señalan la Ley reguladora de los efectos económicos del matrimonio ${ }^{3}$. En consecuencia, y mientras llega ese momento, debe recordarse que quedan

${ }^{1}$ Reglamento (UE) 2016/1103 del Consejo de 24 de junio de 2016 por el que se establece una cooperación reforzada en el ámbito de la competencia, la ley aplicable, el reconocimiento y la ejecución de resoluciones en materia de regímenes económicos matrimoniales (DOUE L 183 de 8 julio 2016).

2 Vid. A. Rodríguez Benot, "Los efectos patrimoniales de los matrimonios y de las uniones registradas en la Unión Europea", CDT, 2019, vol. 11, núm. 1, pp. 8-50; I. ANTÓN JUÁREZ, "La oposición del régimen económico matrimonial y la protección del tercero en Derecho Internacional Privado", CDT, 2017, pp. 59-75; I. ANTÓN JUÁREZ, "Acuerdos prematrimoniales en previsión de ruptura matrimonial: el test conflictual y material a tener en cuenta para que un acuerdo prematrimonial supere una revisión judicial ante tribunales españoles", CDT, 11, 1, 2019, pp. 81-109; I. ANTÓN JUÁREZ, “Acuerdos prematrimoniales internacionales y protección de los menores", en A. Cebrián SALVAT/I. LoRente Martínez (Dir.), Protección de menores y Derecho Internacional Privado, Granada, Editorial Comares, 2019, pp. 117-141; B. AÑoveros Terradas, "El régimen conflictual de las capitulaciones en los nuevos reglamentos de la Unión Europea en materia de regímenes económicos matrimoniales y efectos patrimoniales de las uniones registradas", Anuario español de Derecho internacional privado, 2017, pp. 821-845; J. Bachmann, Die neuen Rom IV-Verordnungen: auf dem Wege zu einem einheitlichen Güterkollisionsrecht für Ehegatten und eingetragene Partner, Remscheid, Gardez! Verlag, 2016, pp. 9-11.

${ }^{3}$ M. ANDRAE, "Der sachliche Anwendungsbereich der Europäischen Güterrechtsverordnung", IPRax, 2018-3, pp. 221-230. 
todavía muchos matrimonios cuyo régimen económico matrimonial se rige por las normas de conflicto españolas, aunque el régimen económico matrimonial deba disolverse con posterioridad a la fecha señalada. Se trata de los arts. 9.2 y $9.3 \mathrm{CC}$. Ello justifica que el presente estudio se dedique a explorar las virtudes, los defectos y también los insondables misterios que ofrecen estos dos preceptos legales. Por otra parte, no debe olvidarse que ambos preceptos se aplican también para fijar cuál es la Ley aplicable al régimen económico matrimonial en casos de Derecho interregional ${ }^{4}$. Tales casos, en efecto, están excluidos del citado Reglamento, como indica el art. 35 del mismo $^{5}$ Y conviene no olvidar que los efectos personales del matrimonio no se regulan por el Reglamento citado 2016/1103, de modo que el art. 9.2 CC es plenamente operativo para fijar la Ley aplicable a dichos efectos personales del matrimonio sea cual fuere la fecha de celebración del mismo.

\section{Ley aplicable a la celebración del matrimonio y Ley aplicable a los efectos del matrimonio}

\section{Matrimonium in fieri y matrimonium in facto esse. Efectos internos y efectos externos del matri- monio}

2. Para analizar de modo correcto el régimen jurídico de los efectos jurídicos del matrimonio, es necesario recordar una clásica distinción que resulta no sólo útil sino imprescindible para el buen fin de cualquier acercamiento al régimen jurídico del matrimonio en Derecho internacional privado.

3. En primer término, el matrimonio es un acto jurídico. La celebración del matrimonio, entendido como acto jurídico (matrimonium in fieri), está sujeta a Leyes estatales distintas, pues en Derecho internacional privado español no existe una norma de conflicto que designa una sola y única Ley estatal (Lex Matrimonii) que regule todos los requisitos exigibles para la válida celebración del matrimonio. La capacidad nupcial y el consentimiento de los contrayentes se rige por su respectiva Ley personal (art. 9.1 $\mathrm{CC}$ ), y la forma del acto se regula por las Leyes designadas a través de los arts. 49 y 50 CC.

4. En segundo lugar, el matrimonio válidamente celebrado genera, de manera necesaria, dos grupos de efectos jurídicos distintos.

Por una parte, el contenido del vínculo jurídico llamado "matrimonio", esto es, los "efectos jurídicos internos" del acto jurídico llamado "matrimonio" ("matrimonium in facto esse"). El matrimonio genera unas especiales "relaciones jurídicas personales y patrimoniales entre los cónyuges", también llamados, aunque de modo impropio, "efectos del matrimonio" (SAP Barcelona 19 enero 2012 [divorcio entre cónyuges antes marroquíes y ahora españoles] $)^{6}$. El presente estudio se centra en exponer, en relación con los casos internacionales, cuál es la Ley aplicable a tales "relaciones entre los cónyuges", la Ley reguladora de los "efectos jurídicos internos del matrimonio".

Por otra parte, el matrimonio repercute en aspectos jurídicos ajenos a su estructura interna: alimentos, sucesiones, nombre de las personas, etc. En dichos supuestos, el matrimonio válidamente celebrado suele operar como una "cuestión previa". Así, puede ser necesario acreditar si existe un "matrimonio válido" como cuestión previa a la sucesión en favor de una mujer que dice ser "viuda del causante". El art. 9.2 CC no resulta aplicable a los efectos que el matrimonio puede surtir en otros órdenes jurídicos: pensiones de viudedad, seguros, sucesiones, alimentos, etc. Estas cuestiones se rigen por la Ley aplicable a tales instituciones (Ley reguladora de la pensión de viudedad, del contrato de seguro, de la sucesión, de los alimentos, etc.). En ocasiones resulta preciso acreditar si el matrimonio existe. Para

\footnotetext{
${ }^{4}$ M. YzQuierdo Tolsada, "El Tribunal Constitucional declara nulos todos los artículos de la Ley, 10/2007, de 20 de marzo, de Régimen Económico Matrimonial Valenciano", CDT, 2016, pp. 330-347.

5 Artículo 35 R.2016/1103: "No aplicación del presente Reglamento a los conflictos internos de leyes. Los Estados miembros que comprendan varias unidades territoriales con sus propias normas en materia de regímenes económicos matrimoniales no estarán obligados a aplicar el presente Reglamento a los conflictos de leyes que se planteen entre dichas unidades territoriales exclusivamente".

${ }^{6}$ SAP Barcelona 19 enero 2012 [CENDOJ 08019370122012100007].
} 
ello debe aplicarse el art. 9.1 CC para determinar la Ley aplicable a la capacidad y el consentimiento de los contrayentes y los arts. 49-50 CC para precisar la Ley reguladora de la forma del matrimonio. El art. 9.2 CC es inaplicable tanto para acreditar la existencia del matrimonio como para determinar los efectos jurídicos externos de tal matrimonio en otras esferas del Derecho, como puede verse en la STSJ Com Madrid Social 12 abril 2010 [matrimonio religioso celebrado en Dinamarca]) 7.

5. Al margen de los casos regulados por el Reglamento $2016 / 1103$ citado que resulta plenamente operativo sólo en relación con matrimonios celebrados tras el 29 enero 2019, en los casos internacionales, los efectos jurídicos internos del matrimonio se rigen, para las autoridades españolas, por la Ley estatal designada por los arts. 9.2 y 9.3 CC. Dicha Ley bien puede ser una Ley extranjera aunque el matrimonio se haya celebrado ante una autoridad española. Así, por ejemplo, en el caso de dos marroquíes con residencia habitual en España que contrajeron matrimonio ante juez español en 2008, la capacidad nupcial y el consentimiento de ambos contrayentes se rigen por la Ley marroquí (art. 9.1 CC), y la forma del matrimonio se regirá por el Derecho español (art. 50 CC). Sin embargo, en este caso, los derechos y obligaciones que derivan de este matrimonio celebrado en España se rigen por el Derecho marroquí y no por el Derecho español (art. 9.2 CC). Es decir, como expresa P. MAYER, en realidad no han contraído un "matrimonio español", los cónyuges no están vinculados por los derechos y obligaciones derivados del matrimonio que establece el Derecho español aunque hayan contraído matrimonio en España y/o ante autoridad civil española. Los derechos y obligaciones derivados de su vínculo matrimonial se rigen por el Derecho marroquí, que es su Ley nacional común ${ }^{8}$.

6. A los propósitos de un análisis jurídico, los efectos internos del matrimonio se dividen en efectos "personales" y efectos "patrimoniales". Los "efectos personales" del matrimonio comprenden todas las relaciones jurídicas entre los cónyuges que derivan del matrimonio y que no presentan contenido económico, como ya expuso E. BARTIN en sus clásicos estudios sobre la calificación ${ }^{9}$. Los efectos patrimoniales del matrimonio hacen referencia a las relaciones económicas entre los cónyuges, a la economía matrimonial, al régimen económico matrimonial, aspecto que en la mayor parte de los ordenamientos jurídicos dispone de una regulación particular.

\section{Efectos personales y efectos patrimoniales derivados del matrimonio}

\section{A) Efectos personales del matrimonio}

7. El Derecho civil español actual recoge una serie de "efectos personales" del matrimonio que revisten una importancia jurídica objetiva innegable, pese a que la doctrina mayoritaria insiste en considerar que tales efectos no presentan relieve jurídico. Se trata de unas pautas generales de comportamiento conyugal relativas a la vida personal en común de los cónyuges. Ejemplos: vivir juntos, guardarse fidelidad, socorrerse mutuamente, compartir las responsabilidades domésticas, y cuidar a las personas dependientes a su cargo (vid. art. $68 \mathrm{CC}$ español). Sin embargo, ese enfoque mayoritario confunde el carácter jurídico de estas indicaciones con la existencia de acciones judiciales directas derivadas de la infracción de las mismas. Es conveniente deslindar ambos perfiles.

En Derecho sustantivo español, el incumplimiento de estas "indicaciones" no da lugar a acciones judiciales directas para reclamar su cumplimiento (= un cónyuge no puede acudir al juez para que obligue al otro cónyuge a guardar fidelidad o compartir las tareas domésticas). Antes de 2005, el incumplimiento de estos deberes constituía una posible causa de separación y/o divorcio. En la actualidad, el

\footnotetext{
${ }^{7}$ STSJ Com Madrid Social 12 abril 2010 [AS 2010/1609].

${ }^{8}$ P. MaYer / V. Heuzé / B. Remy, Droit international privé, 12a ed., Paris, LGDJ, Lextenso, 2019, n. 574.

9 E. BARTin, "La doctrine des qualifications et ses rapports avec le caractere national du conflit de lois", RCADI, 1930, vol.31, pp. 561620; ID., "De l'impossibilité d'arriver à la suppression définitive des conflits de lois", JDI Clunet, 1897, pp. 225255,466495 y 722728 .
} 
incumplimiento de tales "indicaciones" no es causa de separación ni de divorcio (art. 81 y $86 \mathrm{CC}$, redacción por Ley 15/2005, de 8 de julio ${ }^{10}$. Estos deberes no deben ser interpretados como meras indicaciones morales o pautas éticas buenistas. Son deberes jurídicos y por ello están en el Código Civil. Por tanto, el incumplimiento de estos deberes conyugales presenta, no obstante, un doble relieve jurídico. Por un lado, la infracción de las obligaciones personales derivadas del matrimonio puede constituir causa de desheredación (art. 855.1 CC: "haber incumplido grave o reiteradamente los deberes conyugales"). Por otro lado, esta infracción genera responsabilidad civil, pues se trata del incumplimiento de deberes jurídicos, no de deberes morales o de pautas éticas. En consecuencia, casos como infidelidades conyugales causadas con dolo, reiterada falta de participación en las labores domésticas y otras circunstancias lesivas de la integridad moral del cónyuge, generan la posibilidad de ejercitar acción de reclamación de daños y perjuicios de carácter extracontractual (art. 1902 CC) (SAP Asturias 22 abril 2016) ${ }^{11}$.

8. En otros Derechos extranjeros, sin embargo, como ocurre en los Derechos de inspiración musulmana, los efectos personales del matrimonio son todavía muy importantes, recuerda S.A. ALDEEB ABU-SAHLIEH ${ }^{12}$. Ejemplo: el marido paga la nafaqa, institución que comprende manutención, alojamiento, mobiliario, accesorios femeninos como perfumes y cosméticos, etc. A cambio, el marido puede obligar a su esposa a quedarse en casa al cuidado del hogar, a no trabajar fuera de casa, a seguirle donde quiera que vaya, y a mantener relaciones sexuales con él, como muy bien puede ilustran M. AgUILAR Benítez de Lugo / H. Aguilar Grieder, C. Focarelli) ${ }^{13}$. En ciertos ordenamientos jurídicos extranjeros, el incumplimiento de determinadas obligaciones personales derivadas del matrimonio sí es causa de divorcio o puede desembocar en responsabilidad patrimonial.

\section{B) Efectos patrimoniales del matrimonio. Los distintos regímenes económicos matrimoniales en el mundo}

9. La inmensa mayoría de los sistemas jurídicos estatales establecen que el matrimonio da lugar a una situación jurídica particular de la economía matrimonial: es el famoso "régimen económico matrimonial". Desde el punto de vista práctico, subraya G.M. UBERTAZzi, el régimen económico del matrimonio constituye el efecto más relevante del matrimonio ${ }^{14}$. Existen divergencias muy marcadas entre los distintos Derechos estatales en relación con el régimen económico matrimonial, diferencias que, apunta A. BuCHER, han hecho de las normas de conflicto de leyes unas normas de extrema importancia en la litigación internacional ${ }^{15}$. Estas diferencias derivan de las disparidades entre el Derecho Romano y el Derecho germánico. Por ello, en la actualidad, existen cuatro grandes sistemas económicos matrimoniales como expone acreditada doctrina ${ }^{16}$.

10. En primer lugar, el sistema de comunidad universal de bienes, con arreglo al cual todos los bienes que pertenecían a los cónyuges antes del matrimonio, al igual que todos aquéllos que adquieran durante el matrimonio, pasan a integrar una misma masa de bienes, que se disuelve terminado el matrimonio. Se sigue en Países Bajos (SAP Tarragona 13 abril 2011 [régimen económico de cónyuges ho-

\footnotetext{
${ }^{10}$ Ley 15/2015, de 2 de julio, de la Jurisdicción Voluntaria (BOE núm. 158 de 3 julio 2015).

11 SAP Asturias 22 abril 2016 [CENDOJ 33044370042016100154].

12 S.A. Aldeeb Abu-SAhlieh, "Les régimes matrimoniaux en droits arabe et musulman- cas de l'Egypte et du Maroc: normes matérieles et normes de conflit”, Études Suisses de droit comparé, núm. 8, 11 junio 2007 (www.isdc.ch).

13 M. Aguilar Benítez de Lugo / H. Aguilar Grieder, "Alimentos y orden público (I) y (II)”, BIMJ, 15 abril 2006 , núm. 2011, pp. 1561-1593 y núm. 2012 de 1 mayo 2006, pp. 1747-1765; C. FocAREll, Lezioni di diritto internazionale privato, Morlacchi Ed., Perugia, 2006, pp. 2102-104.

${ }^{14}$ G.M. Ubertazzi, "Regles de nondiscrimination et droit international privé", RCADI, 1977, vol.157, pp. 333-414.

15 A. Bucher, "Les régimes matrimoniaux en droit international privé suisse", La Semaine Judiciaire, 1989, pp. 361-380.

16 G.A.L. Droz, "Les régimes matrimoniaux en droit international privé", RCADI, 1974, vol. 143, pp. 1-138; V.L. SIMó SAntonja, Compendio de regímenes matrimoniales, Tirant, Valencia, 2005; E. Gómez CAMPELO, Los regímenes matrimoniales en Europa y su armonización, Madrid, Editorial Reus, S.A., 2008; O. IzQuierdo / A. Oliva RodríGuez / A.M. Oliva IzQuiERdo, Los regímenes económico matrimoniales del mundo, Colegio de Registradores de la Propiedad y Mercantiles de España, 2018.
} 
landeses], Brasil (AAP Barcelona 7 mayo 2012 [comunidad universal de bienes en Derecho brasileño]), África del Sur, países nórdicos cuando el matrimonio ha durado un cierto tiempo, etc. ${ }^{17}$.

11. En segundo lugar, el sistema de radical separación de bienes, según el cual el matrimonio no altera la economía de cada cónyuge. No hay masa de bienes comunes. Es el caso de Grecia, Austria, países de Derecho islámico (SAP Valencia 14 marzo 2019 [régimen económico matrimonial en Derecho marroquí musulmán]; RDGRN [1ㄹ] 21 noviembre 2011 [régimen económico matrimonial marroquí]) y países que admiten la poligamia, así como numerosos Estados americanos, -Chile, Honduras, Nicaragua, Panamá, etc.-, y ciertas Comunidades Autónomas españolas, como Baleares y Cataluña ${ }^{18}$.

12. En tercer lugar, el omnipresente sistema de sociedad de gananciales, que consiste en que se forma una masa de bienes comunes de la que están excluidos los bienes de los cónyuges adquiridos antes del matrimonio, así como los adquiridos tras el matrimonio por título lucrativo, como donaciones o herencias. Pertenecen a la masa común, a la sociedad de gananciales, los bienes que los cónyuges adquieran a título oneroso tras la celebración del matrimonio. Es el régimen más extendido en todo el mundo. Se sigue en el Derecho civil común español, en numerosos países sudamericanos, -en los que la influencia legal española ha sido muy marcada-, en Francia, Italia, Bélgica y países de la esfera exsocialista que siguieron el régimen de gananciales establecido por el Código Soviético de la Familia.

13. En cuarto lugar, el sistema de participación en las ganancias generadas, que se sigue en países como Alemania (Zugewinngemeinschaft), Finlandia, Suiza y Québec, como expone S. NAvaS NAVARRO $^{19}$. Significa que, durante el matrimonio, cada cónyuge mantiene su patrimonio separado e individual. Cuando se disuelve el matrimonio, se debe proceder a computar las ganancias que cada esposo ha obtenido. El cónyuge que haya obtenido más ganancias debe pagar al otro cónyuge la mitad de esa cantidad que ha obtenido de más.

14. En quinto lugar, no deber olvidarse que ciertos países no conocen el concepto de "régimen económico matrimonial". En líneas generales, como muestra V. MARTorell García, los países de Common Law carecen de un régimen económico matrimonial en sus legislaciones ${ }^{20}$. En Gran Bretaña, el concepto de "régimen económico del matrimonio" no existe, apunta F. JUENGER ${ }^{21}$. Por tanto, cuando el Derecho inglés es aplicable en España, no puede activarse ninguna presunción de ganancialidad ni nada parecido ni tampoco cabe ningún procedimiento de liquidación de régimen económico matrimonial (ATS 3 julio 2019 [sociedad de gananciales y Derecho inglés]; SAP Valencia 15 febrero 2018 [Derecho inglés]; SAP Islas Baleares 10 abril 2018 [Derecho inglés], RDGRN 19 octubre 2018 [Ley inglesa]) ${ }^{22}$. El matrimonio no altera en nada la propiedad de cada cónyuge. No obstante, en el Derecho de estos países se sigue un régimen en cuya virtud ciertos bienes adquiridos constante matrimonio o por ambos cónyuges o vinculados a la vida matrimonial, se asignan a la familia o al matrimonio y ciertas deudas son imputables a ambos cónyuges. Al finalizar el matrimonio por divorcio, los tribunales disponen de un poder muy amplio para distribuir los bienes de ambos cónyuges que estaban asignados al funcionamiento del matrimonio, sean propiedad de quien sean, siempre que no se trate de matrimonios de "corta duración". De ese modo, se intenta evitar que un cónyuge quede desfavorecido tras el divorcio después

17 SAP Tarragona 13 abril 2011 [CENDOJ 43148370012011100188]; AAP Barcelona 7 mayo 2012 [CENDOJ 08019370182012200122].

${ }_{18}$ SAP Valencia 14 marzo 2019 [ECLI: ECLI:ES:APV:2019:431]; RDGRN [1ª] 21 noviembre 2011 [JUR 2012/304119].

19 S. Navas Navarro, El régimen de participación en las ganancias desde una perspectiva europea, Madrid, Dykinson, 2014.

${ }^{20}$ V. Martorell García, "Estatuto personal de los británicos y su régimen matrimonial y sucesorio en la práctica notarial española", www.notariosyregistradores.com.

21 F. Juenger, "Marital Property and the Conflict of Laws, A Tale of Two Countries", Columbia Law Review, 1981, vol.81, pp. 1061-1092.

22 ATS 3 julio 2019 [ECLI:ES:TS:2019:7465A]; SAP Valencia 15 febrero 2018 [ECLI:ES:APV:2018:480]; SAP Baleares 10 abril 2018 [ECLI: ECLI:ES:APIB:2018:83A]; RDGRN 19 octubre 2018 [BOE n.291 de 3 diciembre 2018]. 
de haberse dedicado a la familia. Los tribunales dictan diversas medidas (ancilliary relief) ajustadas a los caracteres del caso concreto. Puede afirmarse, en general, que los cónyuges pueden acordar lo que estimen conveniente para distribuir los bienes tras el divorcio, de modo que los tribunales sólo acuerdan medidas sobre este particular si dichos cónyuges no alcanzan un acuerdo.

\section{Cuestiones de Derecho transitorio. El ocaso de la Ley nacional del marido}

15. En el año 1974 el art. 9.3 CC recibe una nueva redacción como consecuencia del nuevo Título Preliminar del Código Civil españo ${ }^{23}$. El precepto indicaba que la Ley aplicable al régimen económico matrimonial en defecto de pacto, era, en último término, la Ley nacional del marido en el momento de la celebración del matrimonio. Dos hipótesis deben distinguirse.

16. Para los matrimonios celebrados antes del 29 diciembre 1978, -fecha inmarcesible de publicación y, al mismo tiempo, de entrada en vigor de la Constitución española-, debe recordarse que el art. 9.3 CC, -redacción de 1974-, fue derogado expresamente por la Ley 11/199024. Sin embargo, lo cierto es que el precepto, cuando remitía a la "Ley nacional del marido" estaba ya derogado tácita pero radicalmente

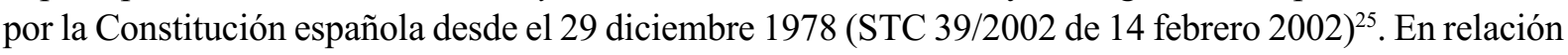
con los matrimonios celebrados antes del 29 diciembre 1978 y cuyos efectos se prolongan después de tal fecha, el Tribunal Constitucional español y, en general, toda la jurisprudencia civil española, afirman que debe aplicarse el antiguo art. 9.3 CC para fijar la Ley reguladora del régimen económico matrimonial de los cónyuges. De ese modo, a falta de nacionalidad común de los cónyuges, todos los efectos legales de estos matrimonios deben quedar sujetos a la Ley nacional del marido, que era la conexión vigente en el momento de celebración del matrimonio. Para estos tribunales, la entrada en vigor de la CE 1978 no produce efecto jurídico alguno sobre estas situaciones jurídicas generadas antes de la Constitución Española de 1978. Los tribunales han preferido esta solución porque, a su juicio, ésta comporta una "permanencia de la Ley aplicable", especialmente al régimen económico matrimonial, y por ello, refuerza la seguridad jurídica de situaciones legales nacidas antes de la CE 1978 (STC 39/2002 de 14 febrero 2002, STS 11 febrero 2005 [aplicación de la Ley de la vecindad civil balear del marido], STS 6 octubre 1986; SAP Barcelona 29 abril 2016 [ley aplicable al régimen económico matrimonial], SAP Barcelona 24 marzo 2009 [aplicación de la Ley nacional del marido, Ley boliviana], SAP Barcelona 20 mayo 2009 [vecindad civil catalana], SAP Castellón 6 octubre 2001, SAP Illes Balears, Sección 4a , de 10 septiembre 2002, SAP Castellón 22 noviembre 2002, STS 24 enero 2006, SAP Las Palmas 5 diciembre 2007 [matrimonio celebrado en Suiza en 1972 entre español y suiza ambos con residencia habitual en España: aplicación de la Ley nacional del marido], SAP Barcelona 12 febrero 2013; RDGRN 15 marzo 2017 [matrimonio entre polaco y española anterior a 1981], RDGRN 11 mayo 2017 [régimen económico de matrimonio celebrado antes de la entrada en vigor de la Constitución de 1978 y sujeto al consorcio aragonés] $)^{26}$.

Debe subrayarse, sin embargo, que no son todo rosas y champaigne lo que deriva de esta tesis. Como ha indicado M.A. Amores ConRADí, en su interés por defender la seguridad jurídica (= las solu-

${ }^{23}$ Vid. de nuevo Decreto 1836/1974, de 31 de mayo, por el que se sanciona con fuerza de ley el texto articulado del Título Preliminar del Código civil (BOE núm. 163 de 9 julio 1974).

${ }^{24}$ La Constitución española fue publicada en BOE núm. 311 de 29 diciembre 1978. Texto original en https://www.boe.es/ diario_boe/txt.php?id=BOE-A-1978-31229. Vid. Ley 11/1990 de 15 de octubre, sobre reforma del Código civil en aplicación del principio de no discriminación por razón de sexo (BOE núm.250 de 18 octubre 1990).

${ }^{25}$ STC 39/2002 de 14 febrero 2002 [RTC 2002/39].

${ }^{26}$ STS 11 febrero 2005 [CENDOJ 28079110012005100058]; STC 39/2002 de 14 febrero 2002 [RTC 2002/39]; SAP Barcelona 29 abril 2016 [CENDOJ 08019370162016100127]; STS 6 octubre 1986 [CENDOJ 28079110011986100949]; SAP Barcelona 24 marzo 2009 [CENDOJ 08019370122009100187]; SAP Barcelona 20 mayo 2009 [CENDOJ 08019370122009100356]; SAP Castellón 6 octubre 2001 [CENDOJ 12040370032001100618]; SAP Illes Balears, Sección 4 a de 10 septiembre 2002 [CENDOJ 07040370042002100276]; SAP Castellón 22 noviembre 2002 [CENDOJ 12040370032002100028]; STS 24 enero 2006 [CENDOJ 28079110012006100052]; SAP Las Palmas 5 diciembre 2007 [CENDOJ 35016370052007100412]; SAP Barcelona 12 febrero 2013 [CENDOJ 08019370182013100046]; RDGRN 15 marzo 2017 [BOE 80 de 4 abril 2017]; RDGRN 11 mayo 2017 [BOE núm. 127 de 29 mayo 2017]. 
ciones jurídicas no deben cambiar en el tiempo) y la certeza legal (= debe mantenerse estable la norma en vigor en el momento de los hechos relevantes), esta tesis comporta la aplicación de normas españolas de Derecho internacional privado contrarias a la Constitución española de 1978 en relación con efectos legales posteriores a la entrada en vigor de la Constitución, lo que resulta, cuanto menos, llamativo ${ }^{27}$. Así, por ejemplo, un apartamento que adquieren en 2020 dos cónyuges de distinta nacionalidad casados en 1977 pertenecerá a la sociedad de gananciales si la Ley nacional del marido indica que es ése el régimen económico matrimonial de la pareja.

17. Para los matrimonios celebrados después del 29 diciembre 1978, pero antes de la entrada en vigor de la Ley 11/1990 debe tenerse presente que, cuando el antiguo art. 9.3 CC remita a la Ley nacional del marido, los efectos del matrimonio celebrados después del 29 diciembre 1978 nunca pueden quedar sujetos a dicha Ley. Esa solución sería contraria a la ya vigente Constitución española de 1978 y como indica el TC, el antiguo art. 9.3 CC, cuando remitía a la "Ley nacional del marido" estaba ya derogado radicalmente por la CE 1978 desde el 29 diciembre 1978 (STC 39/2002 de 14 febrero 2002), como antes se ha afirmado ${ }^{28}$. Se genera así una laguna legal que debe integrarse con arreglo a los mecanismos generales: analogía, costumbre y principios generales del Derecho, lo que abre tres opciones operativas.

Primera: a través de tales instrumentos heurísticos, el tribunal debe emplear un nuevo punto de conexión no discriminatorio y, por tanto, en plena sintonía con la Constitución española de 1978, punto de conexión que conducirá a la Ley aplicable a los efectos jurídicos generados tras el 29 diciembre 1978. Se puede acudir, así, a la Ley de la residencia habitual común de los cónyuges inmediatamente posterior a la celebración del matrimonio o, en su defecto, a la Ley del país de celebración del matrimonio (SAP Barcelona 30 julio 2019 [régimen económico y matrimonio celebrado en 1982]; AAP Barcelona 11 diciembre 2019 [Ley reguladora de los efectos de matrimonio celebrado en 1979]; RDGRN 7 abril $2005)^{29}$. La SAP Badajoz 18 enero 2019 [Fuero del Baylío], en el caso de un matrimonio entre varón de vecindad civil común y mujer aforada al Fuero del Baylío, celebrado tras la entrada en vigor de la Constitución española pero antes de la reforma del art. 9 CC por Ley 11/1990, estima que no puede aplicarse el art. 9.2 CC en su versión vigente al contraer el matrimonio pues remite a la Ley correspondiente a la vecindad civil del varón ${ }^{30}$. Como explica J. Rodríguez RodRigo, al comprobar que ambos cónyuges siempre estuvieron empadronados en Valencia del Ventoso, el tribunal aplica la Ley de la residencia habitual común posterior al matrimonio y aplica el Fuero del Bailío y el régimen de comunidad total de bienes $^{31}$. Todo ello lo justifica, ante la laguna legal, en una aplicación analógica de la norma de conflicto en materia de separación y divorcio contenida en el art. $107 \mathrm{CC}$, texto hoy derogado.

Segunda: sin necesidad de encontrar un nuevo punto de conexión, el tribunal puede decidir cuál es el régimen económico del matrimonio a partir de los datos de hecho del caso. Así, en relación con un matrimonio celebrado entre aragonés y catalán celebrado en 1988, la SAP Huesca 13 enero 2009 [régimen económico matrimonial de cónyuges aragonés y catalán] indica que no puede aplicarse la norma de conflicto hoy vigente (art. 9.2 CC redacción por la Ley 11/1990), pues no lo estaba en 1988, ni tampoco la vigente en 1988, ya que conducía a aplicar la Ley nacional o de la vecindad civil del marido al tiempo

${ }^{27}$ M.A. Amores ConRadí en J.D. GonzÁlez Campos y otros, Derecho internacional privado parte especial, Madrid, 1995, pp. 329-354; M.A. Amores ConRADí, "Las relaciones entre cónyuges en el nuevo Derecho internacional de la familia: valores jurídicos y técnicas de reglamentación", $A D C, 1987$, pp. 89-138; ID., "La nueva ordenación de la ley aplicable a los efectos del matrimonio", Revista jurídica de Castilla-La Mancha, núms. 11-12, enero-agosto 1991, pp. 44-51; M.A. AMORES CONRADí, “Art. 9.2 y 3 CC", AA.VV, Comentarios al Código Civil y a las Compilaciones forales, dirigidos por M. AlbaladeJo y S. Díaz Alabart, tomo I, vol.II, $2^{a}$ ed., Ed.Revista de Derecho privado / Edersa, Madrid, 1995, pp. pp. 181-205; ID., "Régimen económico matrimonial (Derecho internacional privado)", en Vv.AA., Enciclopedia jurídica básica, dirigida por A. MontoYA MeLGAR, Ed.Civitas, Madrid, 1995, pp. 5692-5693.

${ }^{28}$ STC 39/2002 de 14 febrero 2002 [RTC 2002/39].

${ }^{29}$ SAPBarcelona30julio2019 [ECLI:ES:APB:2019:10479];AAPBarcelona11 diciembre2019[ECLI:ES:APB:2019:15256] RDGRN 7 abril 2005 [JUR 2005/210185].

${ }^{30}$ SAP Badajoz 18 enero 2019 [ECLI:ES:APBA:2019:25].

${ }_{31}$ J. Rodríguez Rodrigo, "El fuero del Baylío, a propósito del comentario de la sentencia de la Audiencia Provincial de Badajoz, de 18 enero 2019”, CDT, 11, 2, Octubre 2019, pp. 747-759. 
del matrimonio, ya que es inconstitucional ${ }^{32}$. De modo que el tribunal aplica el régimen de separación de bienes "con fundamento en los actos propios de las partes exteriorizados mediante la elección de ese régimen ante notario en las diversas escrituras públicas de disposición de bienes inmuebles otorgadas constante matrimonio".

Tercera: se puede aplicar retroactivamente la Ley 15/1990, visto que contiene criterios no discriminatorios. Es una tesis del agrado de la DGRN (RDGRN 9 julio 2014 [efectos del matrimonio y Ley alemana como Ley del lugar de celebración del matrimonio] $)^{33}$.

\section{Ley aplicable a los efectos del matrimonio en Derecho internacional privado español. Los ar- tículos 9.2 y 9.3 del Código Civil}

\section{Posición de los arts. 9.2 y 9.3 en el sistema}

18. Las normas de conflicto españolas que determinan la Ley aplicable a los efectos internos del matrimonio datan de 1990. En virtud de la Ley 11/1990 de 15 de octubre, el legislador decidió reunir bajo una misma Ley aplicable, todos los efectos jurídicos del matrimonio. Por ello, en Derecho internacional privado español existe hoy día una única norma de conflicto que determina la Ley aplicable a todos los "efectos del matrimonio", personales y patrimoniales. Esa norma de conflicto es el art. 9.2 CC. El art. 9.2 CC es, apunta J. RodRíGuez RodRigo, la norma fundamental del sistema, es la norma central, la norma que contiene las soluciones generales ${ }^{34}$. La norma cuyos principios inspiradores constituyen las pautas fundamentales para comprender los criterios de Derecho internacional privado del sistema español a la hora de fijar la Ley aplicable a los efectos del matrimonio.

19. En virtud de la Ley $11 / 1990$ de 15 de octubre, el legislador también incorporó otra norma de conflicto, el art. 9.3 CC. Debe subrayarse que es esta norma no se sitúa al mismo nivel operativo que el art. 9.2 CC. El art. 9.3 CC, en efecto, no tiene como objetivo o misión es señalar la Ley aplicable a los efectos patrimoniales del matrimonio ni tampoco señalar la Ley aplicable a las capitulaciones matrimoniales. El art. 9.3 CC es, simplemente, una "cláusula salvatoria". Una disposición legal que determina la Ley aplicable, exclusivamente, a la "validez" de los pactos y capitulaciones matrimoniales. Al ofrecer varias Leyes estatales diferentes con arreglo a las cuales pueden ser válidos estos pactos y capitulaciones matrimoniales, el art. 9.3 CC potencia en gran medida la posibilidad de que tales acuerdos sean válidos.

\section{La norma central. El artículo $9.2 \mathrm{CC}$}

\section{A) Caracteres generales del art. $9.2 \mathrm{CC}$}

\section{a) Unidad de la Ley aplicable a los efectos del matrimonio}

20. El art. 9.2 CC persigue un claro objetivo: que todas las relaciones jurídicas entre los cónyuges, ya sean de carácter personal o patrimonial, que surgen del matrimonio, queden sujetas a una sola y única Ley reguladora. En efecto, el art. 9.2.I CC señala la Ley aplicable a dos aspectos jurídicos distintos: $1^{\circ}$ ) Las relaciones económicas entre los cónyuges y el régimen económico matrimonial; $2^{\circ}$ ) Las relaciones personales entre los cónyuges o "efectos personales" del matrimonio. Este criterio de política jurídica seguido por el legislador español debe considerarse acertado. Por diversos motivos. Se evitan así los arduos e inextricables problemas de "calificación", ya que no siempre es sencillo ca-

\footnotetext{
32 SAP Huesca 13 enero 2009 [CENDOJ 22125370012009100061].

${ }^{33}$ RDGRN 9 julio 2014 [R. 2014/4480].

34 J. Rodríguez Rodrigo, "Capítulo 29. El régimen económico matrimonial en el Derecho Internacional Privado", en M. Yzquierdo Tolsada/M. Cuena Casas (dirs.), Tratado de Derecho de Familia, vol. 4, 2011, pp. 331-416.
} 
lificar ciertos efectos derivados del matrimonio como "personales" o "patrimoniales", señala P. LouIsLuCAs $^{35}$. Se refuerza también, recuerda A.P. ABARCA JunCO, la seguridad jurídica, pues sólo una Ley regula todos los efectos del matrimonio, lo que simplifica las relaciones jurídicas de los cónyuges en casos internacionales ${ }^{36}$.

21. Todos los efectos jurídicos que el matrimonio produce en relación con la situación económica de los cónyuges se rigen por la Ley determinada en virtud del art. 9.2 CC (SAP Tarragona 13 abril 2011 [régimen económico del matrimonio de cónyuges holandeses] ${ }^{37}$. En este sentido, la Ley designada por el art. 9.2 CC determinará si el matrimonio produce el nacimiento ex lege de una sociedad conyugal, como sucede en Derecho español civil común, o de un régimen económico específico para los cónyuges o si no produce ningún efecto legal en la esfera económica de los cónyuges, como sucede en Derecho inglés. Visto que no es frecuente la conclusión de pactos y capitulaciones matrimoniales, en la mayoría de las ocasiones el entero régimen económico matrimonial se determina con arreglo al art. 9.2.I CC, como sucede, también en la mayor parte de los sistemas nacionales de Derecho internacional privado, apuntan A.E. von OvERBECK y L. PALSSON ${ }^{38}$.

La Ley aplicable al llamado "régimen matrimonial primario", -obligaciones de mantenimiento y de contribución impuestas por la ley a los cónyuges para afrontar las necesidades familiares, poderes de administración y representación recíprocos, responsabilidad frente a terceros por las deudas asumidas por uno de los cónyuges en interés de la familia, cualquier que sea el régimen económico matrimonial concreto de los cónyuges-, se determina con arreglo al art. 9.2 CC, pues, subraya M. Verwilghen, este régimen económico matrimonial primario carece de una norma de conflicto ad hoc y las normas que lo regulan no pueden considerarse "leyes de policía"39.

Las previsiones legales que regulan la situación económica de los cónyuges tras el divorcio y que tienen como objetivo disolver la economía del matrimonio deben ser calificadas como un efecto patrimonial del matrimonio, por lo que quedan reguladas por la Ley designada por el art. 9.2 CC, como bien indicas la SAP Barcelona 10 septiembre 2019 [divorcio y dote entre cónyuges marroquíes] ${ }^{40}$. Así las ancillary reliefs o financial reliefs que dictan los tribunales ingleses tras un divorcio deben ser calificadas como resoluciones dictadas en materia de régimen económico matrimonial. Su objetivo es disolver con justicia la economía matrimonial existente hasta el divorcio.

22. El art. 9.2 CC también señala la Ley aplicable a estos "efectos personales" del matrimonio. Dichos efectos personales comprenden todas las relaciones jurídicas entre los cónyuges que nacen ex lege del matrimonio y que no presentan carácter ni contenido económico, como muy bien ha mostrado la ejemplar, y no siempre bien comprendida STJCE 27 febrero 1997, C-220/95, Antonius van den boogaard vs. Paula Laumen ${ }^{41}$.

${ }^{35}$ P. Louis-LuCAS, "Conflits de méthodes en matière de conflits de lois", JDI Clunet, 1956, pp. 774-823. Las cuestiones calificatorias son constantes en este sector, indica T. RAUSCHER, "Ehegüterrechtlicher Vertrag und Verbraucherausnahme? - Zum Anwendungsbereich der EuVTVO", IPRax, 2011-V, pp. 484-487.

${ }^{36}$ A.P. AbarCa JunCo, "Sobre los efectos o relaciones personales entre los cónyuges en DIPr.", REDI, 1983, pp. 43-60.

${ }^{37}$ SAP Tarragona 13 abril 2011 [CENDOJ 43148370012011100188].

38 A.E. von OVERBECK, "Le droit des personnes, de la famille, des successions et des régimes matrimoniaux dans la nouvelle loi suisse sur le droit international privé”, RCDIP, 1988, vol.77, pp. 237-260; ID., Les successions et les régimes matrimoniaux dans le nouveau droit international privé suisse, CEDIDAC, 1988, núm.9, pp. 59-78; L. PALsson, "Rules, Problems and Trends in Family Conflict of Laws- Especially in Sweden”, RCADI, 1986, vol. 199, pp. 378-402.

${ }^{39}$ M. VeRWILGHEN, "Du neuf sur la loi régissant le régime matrimonial primaire", Nouveaux itinéraires en droit (Hommage à François Rigaux), Bibliothèque de la Faculté de droit de l'Université catholique de Louvain, Bruselas, 1993, pp. 581-618. Con ciertas cautelas, C. Gonź́lez Beilfuss, "Reflexiones en torno a la función de la autonomía de la voluntad conflictual en el Derecho internacional privado de familia", REDI, 2020-1, pp. 101-116.

40 SAP Barcelona 10 septiembre 2019 [ECLI:ES:APB:2019:10964].

${ }^{41}$ STJCE 27 febrero 1997, C-220/95, Antonius van den boogaard vs. Paula Laumen, Recopilación, 1997, p. I-11. [ECLI:EU:C:1997:91], cuyo texto puede verse en http://curia.europa.eu/juris/showPdf.jsf?text=\&docid=100481\&pageIndex $=0 \&$ doclang=es\&mode=1st\&dir=\&occ=first\&part=1\&cid=142473: FD 20-22 "... el Juez competente en materia de divorcio en Inglaterra y en el País de Gales dispone de una amplia facultad discrecional para acordar la adopción de medidas económicas. Puede, en particular, ordenar el pago de cantidades periódicas o globales, así como la transmisión de la propiedad 
23. Al margen de los casos en los que los cónyuges han podido concluir un contrato sobre estos aspectos, debe indicarse que la infracción de las obligaciones personales derivadas del matrimonio, como la que se produce en caso de infidelidades conyugales, es una cuestión excluida del Reglamento Roma II 864/2007 [ley aplicable a las obligaciones extracontractuales] (vid. art. 1.2.a RR-II: "Se excluirán del ámbito de aplicación del presente Reglamento: [...] a) las obligaciones extracontractuales que se deriven de relaciones familiares [... $]^{\prime \prime 2}$. La Ley aplicable para concretar si se han infringido tales deberes conyugales extraeconómicos es la Ley designada por el art. 9.2 CC y dicha Ley estatal fijará las consecuencias jurídicas de tales infracciones. Es conveniente aquí seguir la tesis de la "conexión conflictual accesoria": la Ley que rige la existencia de los derechos y deberes derivados del matrimonio, determinada $e x$ art. 9.2 CC, debe regir también, por conexión, las consecuencias de la infracción de tales derechos y deberes. Un ejemplo puede ser ilustrativo de lo anterior. Mujer española contrae matrimonio con varón alemán y fijan su primer domicilio matrimonial en París. La esposa da a luz un hijo que se supone que es hijo del marido alemán. Éste paga la educación y crianza del menor hasta que, cinco años después, se descubre que el menor no es, realmente, hijo del marido, sino de un varón suizo amigo de la familia. El marido solicita daños y perjuicios a su esposa española por infracción de los deberes conyugales. En efecto, el marido afirma que dicha infracción le ha generado un evidente perjuicio patrimonial, pues ha pagado alimentos a un sujeto que no es su hijo y, además, ha perdido su trabajo en la firma en la que trabajaba, que exige de sus trabajadores y asociados, una conducta moral tradicional. Pues bien, la Ley reguladora de los efectos del matrimonio (art. 9.2 CC), que es la Ley francesa ( $=$ Ley del país del domicilio de los cónyuges inmediatamente posterior a la celebración del matrimonio), es la Ley que rige la cuestión de saber si existe, entre los esposos, un "deber de fidelidad" o no existe y en qué términos legales. Y esa misma Ley, la Ley francesa, debe igualmente decidir si dicha infracción legal comporta una indemnización por daños y perjuicios en favor del marido y la cuantía de la misma.

24. La infracción de las obligaciones personales derivadas del matrimonio puede ser causa de divorcio según ciertos Derechos nacionales. La Ley aplicable a la cuestión de saber si ha habido infracción de tales derechos es la Ley designada por el art. 9.2 CC, pero la Ley que regula la cuestión de saber si ello es causa de divorcio es la Ley que rige el divorcio. Dicha Ley se determina con arreglo al Reglamento Roma III 1259/2010 de 20 diciembre $2010^{43}$. La infracción de las obligaciones personales derivadas del matrimonio puede ser causa de desheredación en determinados Derechos nacionales. La Ley aplicable a la cuestión de saber si ha habido infracción de tales derechos es la Ley designada por el art. 9.2 CC, pero la Ley que regula la cuestión de saber si ello es causa de desheredación es la Ley que

de bienes de uno de los esposos a su excónyuge. Por consiguiente, le corresponde decidir mediante una misma resolución sobre las relaciones matrimoniales y las obligaciones alimentarias derivadas de la disolución de un vinculo matrimonial ..... Debido a que, en el marco de un divorcio, un Juez inglés pueda precisamente, mediante una misma resolución, decidir tanto sobre las relaciones matrimoniales como acerca de las obligaciones alimentarias, el Juez del Estado requerido está obligado a distinguir entre los aspectos de la resolución relativos a los regímenes matrimoniales y los que se refieren a las obligaciones alimentarias, teniendo presente, en cada caso, el objetivo especifico de la resolución dictada .... Este objetivo debería poder deducirse de la motivación de la resolución de que se trate. Si de ella resulta que una prestación está destinada a garantizar la manutención de un cónyuge necesitado o si se toman en consideración las necesidades y los recursos de cada uno de los cónyuges para determinar su cuantía, la resolución se refiere a una obligación alimentaria. En cambio, cuando la prestación tiene por objeto únicamente el reparto de los bienes entre los esposos, la resolución se refiere a los regímenes matrimoniales ... procede responder que debe considerarse que una resolución, dictada en el contexto de un proceso de divorcio, por la que se ordena el pago de una cantidad global, asi como la transmisión de la propiedad de determinados bienes de uno de los esposos a favor de su excónyuge, hace referencia a obligaciones alimentarías y, en consecuencia, queda comprendida dentro del ámbito de aplicación del Convenio de Bruselas, en la medida en que tenga por objeto garantizar la manutención de dicho excónyuge. El hecho de que el Juez del Estado de origen haya descartado, en el marco de su resolución, la aplicación de unas capitulaciones matrimoniales carece de importancia a este respecto".

${ }^{42}$ Reglamento (CE) No 864/2007 del Parlamento Europeo y del Consejo de 11 de julio de 2007 relativo a la ley aplicable a las obligaciones extracontractuales («Roma II») (DOUE L 199 de 31 julio 2007).

${ }^{43}$ Reglamento (UE) N. 1259/2010 del Consejo de 20 de diciembre de 2010 por el que se establece una cooperación reforzada en el ámbito de la ley aplicable al divorcio y a la separación judicial (DOUE L 343 de 29 diciembre 2010), conocido como "Reglamento Roma III". 
rige la sucesión mortis causa. Dicha Ley se determina con arreglo al Reglamento sucesorio europeo $650 / 2012^{44}$.

25. En tiempos pasados, cuando todo el estatuto personal estaba sujeto a la misma Ley, a la Ley nacional, los problemas de coordinación entre las distintas normas de conflicto se resolvían de manera sencilla. Capacidad, estado civil, efectos del matrimonio, sucesiones, todos estos aspectos estaban situados bajo la inefable férula de la Ley nacional. Se podía discutir si la conexión "nacionalidad" era o no apropiada, pero debe admitirse que el sistema era coherente. En la actualidad, esa dislocación del estatuto personal de la que certeramente hablaba $\mathrm{CH}$. Rоснат, ha provocado un incremento exponencial de las incoherencias ${ }^{45}$. Un ejemplo puede ser útil para exponer el fenómeno. Así, en ocasiones puede haberse celebrado un matrimonio válido en España entre sujetos del mismo sexo, sujetos nacionales de un país que no admite tales uniones matrimoniales. Ello puede comportar un "desajuste" entre la Ley rectora de los efectos del matrimonio (art. 9.2 CC: Ley nacional común) y la Ley que se aplicó a la formación del matrimonio (arts. 9.1 y 49-50 CC: Ley material española). Ejemplo: dos marroquíes con residencia habitual en España contraen matrimonio en España con arreglo al Derecho sustantivo español (arts. 9.1 y 12.3 CC). Los efectos legales de tal matrimonio se rigen por la Ley sustantiva marroquí (art. 9.2 CC), Ley que ni prevé ni regula los matrimonios entre personas del mismo sexo ni por supuesto sus efectos jurídicos. Dicha Ley puede establecer derechos y obligaciones para el "marido" y para la "esposa". Pues bien, en el caso de que se produzcan estos u otros "desajustes", la Ley que rige estas "cuestiones en serie" o "cuestiones encadenadas" (questions enchaînées), como el "matrimonio" y los "efectos del matrimonio" debe ser una sola Ley estatal. Y dicha Ley debe ser la que se aplicó a la creación de la situación o institución jurídica, como han indicado P. MaYer / V. Heuzé, M. Cocteau-Senn, y E. Fongaro, entre otros ${ }^{46}$. Se trata, cierto es, de una excepción al art. 9.2 CC que se justifica porque se apoya en el jus connubii, ya que refuerza la eficacia del derecho a contraer matrimonio, tal y como argumenta de modo muy convincente P. HAMMJE ${ }^{47}$.

\section{b) Conexiones en cascada}

26. El art. 9.2 CC contiene puntos de conexión estructurados "en cascada" que señalan la Ley aplicable a "distintas situaciones de hecho". El punto de conexión principal es la "nacionalidad común de los cónyuges". Si dicha circunstancia no concurre, se pasa al punto de conexión siguiente, y así, sucesivamente.

\section{c) Puntos de conexión constitucionalizados}

27. Los puntos de conexión contenidos en el art. 9.2.I CC potencian la igualdad constitucional del varón y la mujer. Fueron introducidos por la Ley 11/1990 de 15 octubre, que eliminó la detestable referencia a la "Ley nacional del marido"48. Después de la Constitución de 27 diciembre 1978, pero antes

${ }^{44}$ Reglamento (UE) 650/2012 del Parlamento Europeo y del Consejo de 4 de julio de 2012 relativo a la competencia, la ley aplicable, el reconocimiento y la ejecución de las resoluciones, a la aceptación y la ejecución de los documentos públicos en materia de sucesiones mortis causa y a la creación de un certificado sucesorio europeo (DOUE L 201 de 27 julio 2012).

${ }^{45} \mathrm{CH}$. Rоснат, La dislocation du statut personnel. Étude de droit international privé, Lausanne, Imprimerie Vaudoise, 1986, pp. 33-34.

${ }^{46}$ E. Fongaro, "Le mariage homosexual à l' épreuve du droit international privé”, JDI Clunet, 2006-2, pp. 477 y ss.; D. Cocteau-Senn, Dépecage et coordination dans le réglement des conflits de lois, 2001, thèse de doctorat, Paris 1, 2001, en http:// www.sudoc.abes.fr/cbs/xslt/DB=2.1//SRCH?IKT=12\&TRM=059672706\&COOKIE=U10178,Klecteurweb,D2.1,Eadf4254666,I250,B341720009+,SY,QDEF,A\%5C9008+1,,J,H2-26,,29,,34,,39,,44,,49-50,,53-78,,80-87,NLECTEUR+PSI,R83.37.170. 35,FN; P. MaYer / V. Heuzé / B. Remy, Droit international privé, 12a ed., Paris, LGDJ, Lextenso, 2019, n.574.

${ }^{47}$ P. HammJe, "Mariage pour tous" et droit international privé", RCDIP, 2013, (4), vol. 102, pp. 773-806.

${ }^{48}$ Ley 11/1990 de 15 de octubre, sobre reforma del Código civil en aplicación del principio de no discriminación por razón de sexo (BOE núm.250 de 18 octubre 1990). 
de la Ley 11/1990, los tribunales españoles ya habían declarado que el punto de conexión "Ley nacional del marido" era inconstitucional e inaplicable (STS 6 octubre 1986, SAP Las Palmas 2 febrero 1993, SJPI 2 Telde 30 mayo 1980, SJPI 1 Badalona 15 abril 1988 y SAP Barcelona, Sec.13a 6 abril 1989) ${ }^{49}$.

El Derecho internacional privado español sintoniza en este punto con el Derecho internacional privado de otros países. En efecto, las conexiones discriminatorias para la mujer deben ser eliminadas por efecto de la igualdad constitucional entre hombre y mujer, -Gleichberechtigung von Mann und Frau-, como declaró en una sentencia seminal, en Alemania, el Tribunal constitucional de dicho país (Sent. Tribunal Constitucional Federal Alemania, Sala $1^{a}$, de 4 mayo 1971) y también en Italia, muchos años más tarde, también el Tribunal Constitucional italiano (Sent. Tribunal Constitucional Italia 74/1987 de 5 marzo 1987 y 477/1987 de 10 diciembre 1987) ${ }^{50}$. En España, indica A. BorRÁs Rodríguez, el movimiento anti-discriminación conflictual de la mujer fue más obra del legislador que de los tribunales ${ }^{51}$.

\section{d) Eliminación del conflicto móvil}

28. Los puntos de conexión recogidos en el art. $9.2 \mathrm{CC}$, están "congelados en el tiempo". Esta solución evita problemas de conflicto móvil, potencia la seguridad jurídica, es sencilla y evita fraudes (SAP Barcelona 4 febrero 2015 [cónyuges españoles antes marroquíes]) ${ }^{52}$. Los efectos jurídicos de los matrimonios celebrados antes de la entrada en vigor del actual art. 9.2.I CC se rigen por la Ley designada por el art. 9 CC en su redacción anterior a la Ley 11/1990 de 15 de octubre (Tempus Regit Actum).

\section{B) Los puntos de conexión recogidos en el art. 9.2 CC}

\section{a) Nacionalidad común de los cónyuges}

29. Si los cónyuges ostentan la misma nacionalidad en el momento de contraer matrimonio, la Ley correspondiente a dicha nacionalidad regirá los "efectos del matrimonio".

La Ley nacional común de los cónyuges señalará si éstos pueden pactar un concreto régimen económico matrimonial y en qué medida pueden y/o deben hacerlo (SAP Tarragona 20 octubre 2009 [divorcio entre alemanes con residencia habitual en Cataluña y elección del régimen de separación de bienes con arreglo al Derecho alemán] $)^{53}$. Resulta frecuente que el régimen económico matrimonial recogido en la Ley nacional de los cónyuges extranjeros sea un régimen de separación de bienes o que, según dicha Ley, no exista ningún régimen económico matrimonial entre los cónyuges. Como es natural, la aplicación de dicha Ley en España no vulnera de modo alguno el orden público internacional español (SAP Tenerife 10 septiembre 2013 [régimen económico matrimonial de ciudadanos iraníes]) ${ }^{54}$.

${ }_{49}$ STS 6 octubre 1986 [CENDOJ 28079110011986100949]; SAP Las Palmas 2 febrero 1993 [REDI, 1994, pp. 354-358]; SJPI 2 Telde 30 mayo 1980 [REDI, 1982, pp. 523-529]; SJPI 1 Badalona 15 abril 1988 [RGD, 1989, n.540, pp. 5855-5857]; SAP Barcelona, Sec.13a 6 abril 1989 [RGD, n. 540, pp. 5855-5857].

${ }^{50}$ Sent. TC Federal Alemania, Sala 1a , de 4 mayo 1971, RabelsZ, 1972, pp. 145-162; Sent. Corte Costituzionale Italia núm.477/1987 de 10 diciembre 1987, Gazzetta ufficiale, serie speciale, 16 diciembre 1987, n. 53 / http://www.giurcost. org/decisioni/1987/0477s-87.html; Sent. Corte Costituzionale Italia n.74/1987 de 5 marzo 1987, http://www.giurcost.org/ decisioni/1987/0071s-87.html. Vid. K.F. JuenGER, "The german Constitutional Court and the Conflict of Laws", AJCL, 1972, vol. 20, pp. 290-298; E. JAYME, "La costituzione tedesca e il diritto internazionale privato", RDIPP, 1972, pp. 76-98; V. SALVATORE, "Incostituzionalità parziale dell'art.18 delle preleggi e legge regolatrice del divorzio", RDIPP, 1989, pp. 69-78.

${ }^{51}$ A. Borrás RodríGUEz, "Non discrimination à raison du sexe et modification du droit international privé espagnol", $R C$ $D I P, 1991$, vol.LXXX, pp. 626-634; ID., "No discriminación por razón de sexo, Derecho internacional privado español”, $A D C$, 1991, vol.44, pp. 233-249; ID., “Arts.9.2 y 9.3 Cc.”, AA.VV. (Coordinador, R.Bercovitz Rodríguez-Cano), Comentarios a las reformas del Código civil (Desde la ley 21/1987 de 11 de noviembre a la ley 30/1991, de 20 de diciembre), Tecnos, Madrid, 1993, pp. 447-456.

${ }^{52}$ SAP Barcelona 4 febrero 2015 [CENDOJ 08019370122015100071].

${ }^{53}$ SAP Tarragona 20 octubre 2009 [CENDOJ 43148370012009100343].

${ }^{54}$ SAP Tenerife 10 septiembre 2013 [CENDOJ 38038370012013100310$]$. 


\section{i) El vértigo de la Ley nacional ataca de nuevo}

30. La aplicación de la Ley nacional común de los cónyuges al omento de la celebración del matrimonio refleja el "vértigo de la Ley nacional": los nacionales de un Estado quedan sujetos a la Ley de ese Estado, esto es del país cuya nacionalidad ostentaban en el momento de contraer matrimonio, lo quieran o no y así puede comprobarse en numerosa jurisprudencia (SAP Barcelona 10 septiembre 2019 [divorcio y dote entre cónyuges marroquíes]; SAP Tarragona 28 junio 2018 [cónyuges marroquíes]; SAP Barcelona 25 septiembre 2018 [divorcio entre esposos argentinos]; SAP Barcelona 12 septiembre 2018 [pensión por desequilibrio y cónyuges uruguayos]; SAP Valencia 15 febrero 2018 [divorcio entre cónyuges de nacionalidad portuguesa e inglesa]; STS 3 abril 2018 [cónyuges colombianos]; SAP Soria 26 octubre 2017 [Derecho rumano]; SAP Barcelona 30 mayo 2017 [cónyuges franceses]; SAP Barcelona 4 febrero 2015 [cónyuges españoles antes marroquíes]; RDGRN 3 febrero 2014 [cónyuges rusos]; SAP Barcelona 18 diciembre 2013 [divorcio entre cónyuges búlgaros]; SAP Tenerife 10 septiembre 2013 [régimen económico matrimonial de ciudadanos iraníes]; SAP Barcelona 19 enero 2012 [divorcio entre cónyuges antes marroquíes y ahora españoles]; SAP Tarragona 20 octubre 2009 [divorcio entre alemanes]; SAP Huesca 14 diciembre 2005, SAP Barcelona 24 enero 2006, SAP Madrid 21 octubre 2005 [Ley nacional común ecuatoguineana], STS 2 diciembre 2004 [Ley nacional común cubana] $)^{55}$.

31. En la actualidad, este primer punto de conexión resulta inadecuado por varias razone. En primer lugar, puede perjudicar la "previsibilidad de la Ley aplicable" y comportar costes enormes para los cónyuges, en especial si el Estado del que son nacionales los cónyuges no es el país "más estrechamente vinculado" con el concreto matrimonio (C. v. BAR). En segundo lugar, es una solución poco multicultural que no sintoniza bien con el "libre desarrollo de la personalidad", ya que los cónyuges no pueden elegir libremente el "modelo jurídico de su matrimonio".

\section{ii) Reenvío y Ley nacional común de los cónyuges}

32. La conexión "nacionalidad común de los cónyuges al tiempo del matrimonio" puede verse afectada por la intervención del reenvío de primer grado (art. 12.2 CC). El reenvío no puede aceptarse si con ello se quiebran los principios sustentadores del art. 9.2 CC: unidad e inmutabilidad de la Ley rectora de los efectos del matrimonio (SAP Barcelona 17 abril 2007 [matrimonio entre español y suiza con primer lugar de residencia habitual común en Alemania]). Por tanto, debe rechazarse el reenvío si comporta una aplicación sucesiva o contemporánea de varias Leyes estatales a los efectos del matrimonio.

33. Cabe admitir un "reenvío como instrumento de "ajuste de la localización". En efecto, si el matrimonio presenta una "conexión real" muy débil con el país cuya nacionalidad común ostentaban los cónyuges al tiempo del matrimonio, y por el contrario, el caso concreto presenta una vinculación mucho más estrecha con España, la Ley sustantiva española debe aplicarse a través del reenvío recogido en el art. 12.2 CC. En este caso, el reenvío resulta muy útil para prescindir de la "Ley nacional común" cuando la aplicación de dicha Ley resulta totalmente imprevisible para los cónyuges. Ejemplo: los efectos del matrimonio en el caso de dos ingleses se rigen por la Ley inglesa (Ley nacional común de los

\footnotetext{
${ }^{55}$ SAPBarcelona 10septiembre2019[ECLI:ES:APB:2019:10964];SAPTarragona28junio2018[ECLI:ES:APT:2018:1014]; SAPBarcelona 25 septiembre2018 [ECLI:ES:APB:2018:8937]; SAPBarcelona 12 septiembre2018 [ECLI:ES:APB:2018:7603]; SAP Valencia 15 febrero 2018 [ECLI:ES:APV:2018:480]; STS 3 abril 2018 [ECLI: ECLI:ES:TS:2018:1228]; SAP Soria 26 octubre 2017 [ECLI:ES:APSO:2017:218]; SAP Barcelona 30 mayo 2017 [ECLI:ES:APB:2017:4946]; SAP Barcelona 4 febrero 2015 [CENDOJ 08019370122015100071]; RDGRN 3 febrero 2014 [R. 2014/1974]; SAP Barcelona 18 diciembre 2013 [CENDOJ 08019370122013100918]; SAP Tenerife 10 septiembre 2013 [CENDOJ 38038370012013100310]; SAP Barcelona 19 enero 2012 [CENDOJ 08019370122012100007]; SAP Tarragona 20 octubre 2009 [CENDOJ 43148370012009100343]; SAP Huesca 14 diciembre 2005 [AC 2377]; SAP Barcelona 24 enero 2006 [CENDOJ 08019370122006100064]; SAP Madrid 21 octubre 2005 [CENDOJ 28079370222005100457]; STS 2 diciembre 2004 [CENDOJ 28079110012004101161].
} 
esposos). El DIPr. inglés indica que la propiedad de los bienes muebles de los esposos se rige por la Ley del país de domicilio de los esposos, y la propiedad de los inmuebles se rige por la Ley de situación de tales inmuebles. Pues bien: si los cónyuges siempre han vivido en España y llevan viviendo en España largos años, y en España tienen todos sus bienes, España es el país más estrechamente vinculado con el caso, de modo que la aplicación de la Ley española es previsible para las partes y refuerza la seguridad jurídica. En tal sentido, resulta muy acertada la SAP Málaga de 7 febrero 1994, una resolución pionera en considerar que el reenvío es un instrumento para conseguir la mejor localización ${ }^{56}$.

34. Puede suceder que el art. $12.2 \mathrm{CC}$ remita a un Derecho extranjero en el que esté vigente un convenio internacional no ratificado por España que contenga puntos de conexión que conduzcan a la aplicación del Derecho español. En tal caso, el juez español aplicará dicho convenio internacional aunque no esté vigente para España porque sí lo está para el Derecho cuyo Derecho ha sido designado por el art. 12.2 CC. Así, puede llegarse a la aplicación del Derecho español por ser el Derecho del país donde los cónyuges que ostentan nacionalidad común tienen su primera residencia habitual post-matrimonio si ésta es la conexión empleada por el convenio internacional vigente en el país en cuestión. Es el caso objeto de la SAP Madrid 30 septiembre 2019 [cónyuges holandeses] imaginativamente comentada por J. CARRASCOSA GONZÁLEZ ${ }^{57}$. Dos cónyuges holandeses contrajeron matrimonio en Holanda. La Ley aplicable a su régimen económico matrimonial es el Derecho holandés, por mandato del art. 9.2 CC. Ahora bien, en Derecho holandés está vigente el Convenio sobre Ley aplicable a los regímenes matrimoniales hecho el 14 marzo 1978. Dicho convenio establece que, a falta de elección de Ley por los cónyuges, el régimen económico del matrimonio se rige por la "Ley interna del Estado en cuyo territorio establezcan su primera residencia habitual después del matrimonio". Así pues, en principio existiría un reenvío en favor de la Ley española. Sin embargo, el art. 4.2.b) del Convenio referido indica que el régimen matrimonial se regirá por la ley interna del Estado de la nacionalidad común de los cónyuges si el Estado en el que los cónyuges han instalado su residencia habitual tras el matrimonio "no sea parte en el Convenio, si su ley interna es aplicable según su Derecho internacional privado y los cónyuges establecieran su primera residencia habitual después del matrimonio", lo que sucedía en el caso en cuestión en relación con España. En consecuencia, se aplicó el Derecho holandés, Ley nacional común de los cónyuges.

\section{iii) Conflicto móvil y nacionalidad de los cónyuges}

35. El art. 9.2.I CC toma en consideración la "nacionalidad común" de los cónyuges "en el momento de contraer matrimonio". Se refiere a la nacionalidad común de los cónyuges si éstos la ostentan antes del matrimonio y no si la adquieren por el hecho del matrimonio. De ese modo el legislador evita el conflicto móvil. En efecto, la Ley aplicable a los efectos del matrimonio, determinada por la común nacionalidad de los cónyuges, no varía aunque éstos cambien de nacionalidad posteriormente a la celebración del matrimonio (SAP Barcelona 4 febrero 2015 [cónyuges españoles antes marroquíes], SAP Asturias 6 septiembre 2013 [divorcio entre cónyuges ingleses pero que, al tiempo del matrimonio eran uno inglés y otra venezolana], SAP Girona 18 abril 2013 [régimen económico matrimonial de cónyuges de vecindad civil común en Cataluña], SAP Barcelona 29 febrero 2012 [régimen económico matrimonial de cónyuges argentinos en el momento del matrimonio pero italianos en el momento del divorcio], SAP

${ }^{56}$ SAP Málaga de 7 febrero 1994, REDI, 1995, pp. 232-235. Sobre el reenvío y el ajuste de la localización, vid. A.-L. CALVO Caravaca, "Sucesión hereditaria", en J.D. GonzÁlez Campos y otros, Derecho internacional privado parte especial, 1995, pp. 393-422; A.-L. Calvo Caravaca / J. Carrascosa González, "Sucesión internacional y reenvío", Estudios de Deusto, vol. 55/2, Julio-Diciembre 2007, pp. 59-121; I. Lorente Martínez, "La sentencia del Tribunal Supremo de 12 de enero de 2015. Derecho Sucesorio Internacional y lectura económica del reenvío", CDT, 2015, pp. 466-475.

${ }^{57}$ SAP Madrid 30 septiembre 2019 [ECLI:ES:APM:2019:8814]. Vid. J. CARrascosa GonzÁLEz, "Cuando el Derecho internacional privado hace posible lo imposible: aplicación por tribunales españoles de convenios internacionales no en vigor para España", en http://accursio.com/blog/?p=1031 (consultado el 17 mayo 2020). 
Barcelona 19 enero 2012 [divorcio entre cónyuges antes marroquíes y ahora españoles] $)^{58}$. Ahora bien, un inconveniente surge en el caso de que resulte aplicable la Ley de un país que, en el momento del litigio ya no presenta vinculación alguna con la situación, una Ley de aplicación imprevisible para los cónyuges.

\section{iv) Apatridia y nacionalidad indeterminada de los cónyuges}

36. Si uno de los contrayentes, o ambos, es apátrida o su nacionalidad es indeterminada, debe acudirse al art. 9.10 CC y, en su caso, al art. 12.1 de la Convención de Nueva York sobre el estatuto de los apátridas de 28 septiembre $1954^{59}$. Se considerará, por lo tanto, como "Ley personal" de tal sujeto la que corresponda a su "domicilio", "residencia" o "residencia habitual", según los casos.

\section{v) Efectos del matrimonio entre españoles en casos internacionales e interregionales}

37. Cuando se trata de matrimonio entre españoles, la Ley aplicable a los efectos del matrimonio es la Ley española (art. 9.2.I CC: conexión nacionalidad común). Ahora bien, visto que en España coexisten distintas legislaciones sobre efectos del matrimonio, debe perfilarse qué Derecho Privado español, común o foral, rige los efectos del matrimonio. El legislador español ha previsto varias soluciones para este caso concreto (art. 16.1 y $3 \mathrm{CC}$ ), soluciones que arranca de una premisa metodológica básica: la Ley personal de cada cónyuge será la Ley que corresponde a su vecindad civil (art. 16.1.1 ${ }^{\circ} \mathrm{CC}$ : "Será ley personal la determinada por la vecindad civil").

Primera solución. Si los arts. 9.2 y 3 CC conducen a la aplicación de "una" legislación española, ésta es aplicable. En efecto, el art. 16.3 in primis CC indica que "[l]os efectos del matrimonio entre españoles se regularán por la ley española que resulte aplicable según los criterios del artículo 9" (SAP Navarra 31 julio 2003 [cónyuges con vecindad civil navarra y conquistas]; STS 28 enero 2000 [el régimen económico del matrimonio entre cónyuges con vecindad civil catalana es el de separación de bienes del Derecho catalán] $)^{60}$. Ejemplo: si madrileña y murciano se casan en París, ciudad donde instalan su primera residencia habitual común, la Ley aplicable a los efectos de su matrimonio es la Ley española y en concreto, el Derecho español civil común, pues ambos disponen de la misma Ley personal, ambos ostentan la misma vecindad civil, la vecindad civil común.

Segunda solución. Si los arts. 9.2 y 3 CC conducen a una Ley que no sea española, se aplicará la regulación de los efectos del matrimonio recogida en el Código Civil. En efecto, el art. 16.3 in primis CC indica que "[l]os efectos del matrimonio entre españoles se regularán por la ley española que resulte aplicable según los criterios del artículo 9 y, en su defecto [esto es: cuando no exista "una" ley española única que según el art. 9.2 y 3 CC] por el Código civil". Ejemplo: si madrileña y catalán contraen matrimonio en Berlín, ciudad donde instalan su primera residencia habitual común, la Ley aplicable a los efectos de su matrimonio debería ser la Ley alemana (art. 9.2 CC conexión tercera, pues no existe una Ley personal común, vista la diferente vecindad civil de los cónyuges). Pues bien, el art. $16.3 \mathrm{CC}$ reacciona ante esta solución e indica que la Ley aplicable debe ser la Ley española (= ambos cónyuges son españoles) y en concreto, la regulación sustantiva de los efectos del matrimonio recogida en el Código civil, lo que incluye, naturalmente, el régimen de gananciales como régimen supletorio o general. Esta solución es criticable. En efecto, esta solución otorga al Derecho Civil común un carácter general que no está justificado, una preferente aplicación en perjuicio de los Derechos Civiles autonómicos, como señala C.I. Asua GonZÁLez ${ }^{61}$.

${ }^{58}$ SAP Barcelona 4 febrero 2015 [CENDOJ 08019370122015100071]; SAP Asturias 6 septiembre 2013 [CENDOJ 33044370042013100262]; SAP Girona 18 abril 2013 [CENDOJ 17079370012013100130]; SAP Barcelona 19 enero 2012 [CENDOJ 08019370122012100007]; SAP Barcelona 29 febrero 2012 [CENDOJ 08019370122012100103].

${ }^{59}$ Convención sobre el estatuto de los apátridas, hecha en Nueva York el 28 septiembre 1954 (BOE núm. 159 de 4 julio 1997).

${ }^{60}$ SAPNavarra 31 julio 2003 [CENDOJ 31201370022003100270]; STS 28 enero 2000 [CENDOJ 28079110012000101705].

${ }^{61}$ C.I. Asua González, "Algunas cuestiones en relación al régimen civil aplicable a los efectos del matrimonio entre personas de distinta vecindad civil, el párrafo tercero del art. 16 CC", Revista jurídica de Castilla-La Mancha, núms.11-12, enero-agosto 1991, pp. 73-88. 
Tercera solución. Para reducir los efectos negativos de la solución anterior, el art. 16.3 in fine CC indica que si, a tenor de los arts. 9.2 y $3 \mathrm{CC}$ la Ley reguladora de los efectos del matrimonio no es una sola y única Ley española, "se aplicará el régimen de separación de bienes del Código civil si conforme a una y otra ley personal de los contrayentes hubiera de regir un sistema de separación".

Un primer ejemplo puede resultar útil para comprender el funcionamiento de tan curiosa disposición legal. Varón de vecindad civil catalana y mujer de vecindad civil balear y mallorquina] contraen matrimonio en Palma de Mallorca e instalan su residencia habitual en el Puerto de Santa María. La Ley aplicable a su régimen económico matrimonial debería ser el Derecho civil común español (art. 9.2 CC, conexión tercera: residencia habitual común inmediatamente posterior a la celebración del matrimonio). Ahora bien, ello llevaría a la aplicación del régimen de gananciales previsto en el Código civil cuando, paradójicamente, tanto el Derecho catalán como el Derecho mallorquín recogen como régimen general supletorio a falta de capitulaciones matrimoniales, el régimen de separación de bienes. Pues bien, ante ello, el art. 16.3 CC indica que se aplicará el régimen de separación de bienes previsto en el Código civil español (SAP Cádiz 10 abril 2019 [régimen económico matrimonial y vecindad civil catalana y mallorquina]) ${ }^{62}$.

Un segundo ejemplo también puede ayudar. Matrimonio celebrado en Estambul entre española de vecindad civil balear y español de vecindad civil catalana, ambos con residencia habitual en Turquía. Se debe aplicar la regulación sustantiva del régimen de separación contenida en el Código Civil y no el régimen catalán ni el balear de separación de bienes.

Tras esta solución late una idea inveterada e inmarcesible: el conflicto de leyes se produce entre dos legislaciones que recogen la separación de bienes (= las leyes nacionales de cada uno de los cónyuges), por lo que resulta absurdo e imprevisible para los cónyuges que se acabe en la aplicación de una tercera legislación que impone un régimen de gananciales. El legislador piensa que no hay un verdadero conflicto de leyes entre ordenamientos jurídicos que recogen, ambos, la separación de bienes como régimen económico matrimonial en defecto de pacto. Es curiosa de todos modos la solución, pues, con arreglo al ejemplo antes expuesto, el conflicto de leyes entre el Derecho catalán y el Derecho balear se solventa con la aplicación del Derecho civil común español. Vence el conflicto de leyes la legislación que no interviene en dicho conflicto: tertium datur.

\section{b) Elección de Ley por los cónyuges}

\section{i) Condiciones para una válida elección de Ley}

38. Si los cónyuges no ostentan nacionalidad común, el art. 9.2.I CC permite a los cónyuges, dentro de ciertos límites, elegir la Ley reguladora de los "efectos del matrimonio". Es un punto de conexión vanguardista que el legislador español copió en 1990 del Derecho internacional privado alemán. La Ley elegida por los cónyuges regulará todos los efectos del matrimonio, personales y patrimoniales.

39. Los cónyuges pueden elegir las siguientes leyes estatales en el marco del art. 9.2 CC: (a) Ley personal de cualquiera de los cónyuges en el momento de contraer matrimonio; (b) Ley de la residencia habitual de cualquiera de los cónyuges en el momento de contraer matrimonio. Es dudoso que los cónyuges puedan elegir, ante el silencio del precepto al respecto, una Ley estatal que regule los "efectos personales" y otra Ley diferente que regule los "efectos patrimoniales" del matrimonio. Parece más adecuado sostener la tesis negativa, pues el art. 9.2 CC está edificado sobre la idea regulativa fundamental de la unidad de la Ley reguladora de todos los efectos jurídicos del matrimonio.

40. Para una válida elección de Ley aplicable a los efectos del matrimonio, el art. 9.2.I CC exige la concurrencia de varios requisitos.

${ }^{62}$ SAP Cádiz 10 abril 2019 [ECLI:ES:APCA:2019:411]. 
En primer término, la elección de Ley debe constar en "documento auténtico". Documento auténtico es un documento otorgado ante funcionario público, generalmente un notario o equivalente, que puede ser español o extranjero.

En segundo lugar, la elección de Ley debe ser anterior a la celebración del matrimonio. No se especifica el momento en el que debe llevarse a cabo, por lo que la elección puede ser muy anterior a la celebración del matrimonio. La elección de Ley no surte efectos jurídicos si el matrimonio no llega a celebrarse.

En tercer lugar, la Ley debe ser elegida "por ambos cónyuges". Ello evita fraudes e "imposiciones de ley" por parte de alguno de los cónyuges. El legislador ha exigido un acto personalísimo. Por ello no debe aceptarse que un contrayente otorgue un "poder de representación" en favor del otro contrayente para que elija, también en su nombre, la Ley aplicable a los efectos del matrimonio. El fedatario público se cerciorará de este extremo. Ahora bien, cuando eligen dicha Ley aplicable, los cónyuges no son todavía tales. Son "contrayentes", visto que la elección de la Ley aplicable debe, necesariamente, llevarse a cabo antes de la celebración del matrimonio. Debe entenderse que el art. 9.2 CC, aunque alude a la Ley elegida por los "cónyuges", se refiere, en realidad a "los (futuros) cónyuges".

En cuarto lugar, los cónyuges sólo pueden elegir la Ley reguladora de los efectos del matrimonio si, en el momento de la celebración del mismo, no ostentan la misma nacionalidad. Ello comporta una evidente discriminación por razón de la nacionalidad: los sujetos que ostentan la misma nacionalidad no pueden elegir la Ley reguladora de los efectos de su matrimonio.

En quinto término, la Ley que rige la capacidad para elegir la Ley aplicable es la Ley nacional de cada cónyuge (art. 9.1 CC). La Ley que debe regir el consentimiento y sus posibles vicios es la Ley presuntamente elegida por los cónyuges. Esta solución evita el Forum Shopping y proporciona seguridad jurídica.

En sexto lugar, el art. 9.2 CC no exige que la elección de la Ley aplicable a los efectos del matrimonio sea expresa. Por tanto, con U.P. GRUBER, puede afirmarse que los cónyuges podrían indicar, simplemente que los efectos de su matrimonio se someten, por ejemplo, a "la Ley del país de la residencia del esposo" o "por la Ley del país de la nacionalidad de la esposa"63. En esta línea, el TS ha admitido una elección tácita de dicha Ley aplicable los efectos del matrimonio (STS 28 abril 2014 [sucesión hereditaria de causante italiano] $)^{64}$. Para el TS, si los cónyuges indican en capitulaciones matrimoniales que su residencia habitual común tras el matrimonio estará localizada en España, se produce una elección tácita de la Ley española a los efectos de dicho matrimonio. En realidad, el resultado es el mismo que el que se produciría de no existir dicho pacto, ya que a falta de nacionalidad común de los cónyuges la Ley reguladora de los efectos del matrimonio es la Ley del país de la residencia habitual común inmediatamente posterior a la celebración del matrimonio.

41. Una vez elegida la Ley aplicable a los efectos del matrimonio, dicha Ley es inmutable en el tiempo. Por eso, puede suceder que los esposos se hallen, años después de celebrado el matrimonio, en circunstancias alejadas del país cuya Ley eligieron antes de contraer matrimonio. Ello puede perjudicar sus intereses. Pero que no cunda el pánico: los cónyuges siempre pueden otorgar capitulaciones matrimoniales con arreglo a otra Ley en el marco del art. 9.3 CC. Lo que sí permanece inamovible es la Ley reguladora de los efectos personales del matrimonio, algo que no es adecuado ni justo.

\section{(ii) Ventajas prácticas de una elección de Ley en el contexto del art. 9.2 CC}

42. Las ventajas del punto de conexión "elección de Ley" en el plano práctico son diversas. Permite a los cónyuges la elección de la Ley aplicable a los efectos de su matrimonio potencia el "libre desarrollo de la personalidad", principio constitucional, según indica F. STURM en su ya clásico trabajo ${ }^{65}$ :

\footnotetext{
${ }^{63}$ U.P. Gruber, "Die konkludente Rechtswahl im Familienrecht (KG, S. 71)", IPRax, 2014-1, pp. 53-57.

${ }^{64}$ STS 28 abril 2014 [CENDOJ 28079110012014100234].

${ }^{65}$ F. STURM, "Parteiautonomie als bestimmender Faktor im internationalen Familien- und Erbrecht", en Recht und Rechtserkenntnis, Festschrift Ernst Wolf, Köln, 1985, pp. 637-658.
} 
cada pareja de cónyuges elige la Ley que responde al "modelo matrimonial" preferido. Por otra parte, la posibilidad de elegir la Ley aplicable favorece la integración voluntaria de los cónyuges emigrantes extranjeros en el contexto social y jurídico del "país de acogida". Sin embargo, también permite que dichos cónyuges mantengan las vinculaciones culturales y/o jurídicas con su país de origen. Por ello, la conexión potencia una auténtica sociedad multicultural que se construye sobre el intercambio de valores entre culturas diferentes. Debe tenerse presente también que la elección de Ley es una solución sencilla: favorece la seguridad y previsibilidad de la Ley aplicable. Y es una solución "abierta a resultados materiales", pues los cónyuges elegirán la Ley cuyo contenido sustancial les resulte más favorable. Además, esta solución puede potenciar la unidad de la Ley aplicable a las relaciones de familia -celebración del matrimonio, relaciones de filiación, etc.-

43. No debería admitirse un reenvío de primer grado en relación con la Ley elegida por las partes en virtud del art. 9.2.I CC. Ello frustraría las expectativas de las partes, pues se entiende que cuando éstas eligen un Derecho estatal, eligen un Derecho estatal "sustantivo". Por ello, puede presumirse que la posibilidad de elección de Ley contenida en el art. 9.2.I CC se refiere, exclusivamente, a las normas materiales del Derecho estatal elegido por los cónyuges.

\section{c) Residencia habitual común}

44. Si los cónyuges no ostentan nacionalidad común y no han elegido la Ley reguladora de los efectos del matrimonio, éstos se rigen por la Ley del país de "residencia habitual común de los cónyuges inmediatamente posterior a la celebración del matrimonio". La emergencia de este punto de conexión, algo evidente en el Reglamento 2016/1003, señala B. HEIDERHOFF, contrasta con el papel relegado que despliega en el art. 9.2 CC, siempre por detrás no sólo de la autonomnía de los cónyuges, sino de la Ley nacional común de los mismos ${ }^{66}$.

45. La "residencia habitual común" de los cónyuges es una "noción fáctica". Corresponde al lugar que constituye el "centro de la vida de la familia", con independencia de que los cónyuges estén oficialmente domiciliados, inscritos o empadronados en dicho Estado o en otro. La "residencia habitual" implica "permanencia física" de los cónyuges en un lugar (domus colere) y "voluntad de permanecer" establemente (animus manendi) en un país (SAP Barcelona 7 mayo 2019 [régimen económico matrimonial entre cubana e italiano]; SAP Valencia 15 febrero 2018 [divorcio entre cónyuges de nacionalidad portuguesa e inglesa]; SAP Tarragona 18 enero 2017 [régimen de separación de bienes catalán]; SAP Barcelona 25 febrero 2014 [menor colombiano], SAP Barcelona 5 marzo 2014 [nacionalidad francesa de demandante y española del demandado y doble nacionalidad de los hijos comunes con residencia habitual en Cataluña], SAP Asturias 6 septiembre 2013 [divorcio entre cónyuges con residencia habitual en Inglaterra], SAP Barcelona 3 junio 2013 [divorcio entre español y dominicana] ${ }^{67}$.

Muy bien indica, en este sentido, la SAP Cádiz 10 abril 2019 [régimen económico matrimonial y vecindad civil catalana y mallorquina] que "por residencia habitual debemos entender la residencia real con ánimo y vocación de permanencia en el mismo lugar y no la meramente coyuntural"68. Si los cónyuges residen en el mismo país pero no residen de manera "habitual", el punto de conexión no opera. La prueba de la residencia habitual común compete a las partes, como bien precisa la SAP Las Palmas 5 diciembre 2007 [matrimonio celebrado en Suiza entre español y suiza ambos con residencia habitual en España $]^{69}$.

${ }^{66}$ B. Heiderhoff, "Die EU-Güterrechtsverordnungen", IPRax, 2018-1, pp. 1-11.

${ }^{67}$ SAP Barcelona 7 mayo 2019 [ECLI:ES:APB:2019:4774]; SAP Valencia 15 febrero 2018 [ECLI:ES:APV:2018:480]; SAP Tarragona 18 enero 2017 [ECLI:ES:APT:2018:33]; SAP Barcelona 25 febrero 2014 [CENDOJ 08019370122014100153]; SAP Barcelona 5 marzo 2014 [CENDOJ 08019370122014100154]; SAP Asturias 6 septiembre 2013 [CENDOJ 33044370042013100262]; SAP Barcelona 3 junio 2013 [CENDOJ 08019370122013100397].

68 SAP Cádiz 10 abril 2019 [ECLI:ES:APCA:2019:411].

${ }^{69}$ SAP Las Palmas 5 diciembre 2007 [CENDOJ 35016370052007100412]. 
46. El punto de conexión "residencia habitual común" está fijado en el tiempo. Debe considerarse la residencia habitual común pero sólo si es "inmediatamente posterior a la celebración del matrimonio". Esta precisión temporal plantea problemas tan complejos como fascinantes que conviene analizar cum grano salis.

47. El precepto no se refiere a la "primera residencia habitual común" de los cónyuges una vez celebrado el matrimonio. El precepto se refiere, por el contrario, a una residencia habitual "común" e "inmediatamente posterior a la celebración del matrimonio". Por tanto, si celebrado el matrimonio, la residencia habitual común no se fija inmediatamente, sino que se concreta en un momento posterior, momento hasta el cual los cónyuges residen habitualmente en países diferentes, este tercer punto de conexión no opera (SAP Zaragoza 28 febrero 2003) ${ }^{70}$.

48. Este punto de conexión ha sido fijado en el tiempo por el legislador para evitar problemas de conflicto móvil y para reforzar la seguridad jurídica y la previsibilidad de la Ley aplicable para las partes (SAP Barcelona 29 enero 2018 [matrimonio con primera residencia en Aragón y posterior en Cataluña]; SAP Barcelona 30 junio 2009 [divorcio entre austríaco y española con residencia común en España], SAP Barcelona 17 abril 2007 [matrimonio entre español y suiza con primer lugar de residencia habitual común en Alemania]) $)^{71}$. En efecto: si los cónyuges han residido en varios países, sólo es relevante el país en el que fijan su residencia habitual inmediatamente después del matrimonio. Los cambios posteriores de residencia habitual de los cónyuges a otros países son irrelevantes (SAP Barcelona 19 marzo 2003) ${ }^{72}$.

49. Si los cónyuges contraen matrimonio y tardan un cierto tiempo en fijar su residencia habitual en un país concreto, debe examinarse la intención de los cónyuges. Dos hipótesis surgen, muy bien ilustradas por la ejemplar SAP Granada 13 abril 2005: (a) Si permanecen en un país, por escaso tiempo que sea, pero con voluntad de permanencia estable en dicho país, la Ley de dicho Estado será aplicable a los efectos del matrimonio; (b) Si la permanencia en el "primer país" es meramente transitoria, provisional, accidental y muy breve, y se trasladan posteriormente a un "segundo país", donde fijan su primera residencia habitual común, la Ley de este segundo país será aplicable a los efectos del matrimonio ${ }^{73}$. Así puede verse en la SAP Baleares 13 febrero 2019 [régimen económico de matrimonio entre rusa y alemán celebrado en Moscú]: tras el matrimonio en Rusia, un mes más tarde el esposo se trasladó a vivir a Mallorca y la esposa lo hizo cuatro meses después: la residencia habitual común inmediatamente posterior a la celebración del matrimonio está en Mallorca ${ }^{74}$. Es irrelevante que, según la esposa, hayan vivido en Mallorca con arreglo al régimen de "comunidad de bienes". La Ley aplicable es la española y en concreto la Ley balear y mallorquina, que fija un régimen de separación de bienes.

50. Si los cónyuges otorgan un documento en el que expresan cuál es el "lugar de su residencia habitual común inmediatamente posterior a la celebración del matrimonio", dicha declaración documental no vincula al juez español. El juez debe comprobar en qué verdadero "lugar" radica la "residencia habitual común inmediatamente posterior a la celebración del matrimonio" (RDGRN [3a ] 8 enero 2004) $)^{75}$.

51. Este punto de conexión es operativo también en relación con cuestiones de Derecho interregional, como puede apreciarse entre otras muchas, en la SAP Girona 10 junio 2014 [Ley catalana rectora de los efectos del matrimonio] $]^{76}$.

\footnotetext{
70 SAP Zaragoza 28 febrero 2003 [CENDOJ 50297370042003100045].

71 SAP Barcelona 29 enero 2018 [ECLI:ES:APB:2018:1058]; SAP Barcelona 30 junio 2009 [CENDOJ 08019370182009100329]; SAP Barcelona 17 abril 2007 [CENDOJ 08019370182007100180].

72 SAP Barcelona 19 marzo 2003 [CENDOJ 08019370122003100168].

73 SAP Granada 13 abril 2005 [JUR 2005/138285].

${ }^{74}$ SAP Baleares 13 febrero 2019 [ECLI:ES:APIB:2019:165].

${ }^{75}$ RDGRN [3 $\left.3^{\mathrm{a}}\right] 8$ enero 2004 [R. 2004/2371].

${ }^{76}$ SAP Girona 10 junio 2014 [CENDOJ 17079370012014100186].
} 


\section{d) Lugar de celebración del matrimonio}

52. Si los cónyuges ostentan distinta nacionalidad, no han elegido la Ley reguladora de los efectos del matrimonio, y no han fijado una residencia habitual común inmediatamente posterior al matrimonio, se aplicará la Ley del país de celebración del matrimonio. Así, puede verse el funcionamiento de la conexión en el caso de una mujer cubana y un varón español que contrajeron matrimonio en Cuba. Tras el matrimonio, los cónyuges continuaron viviendo cada uno en su país, y sólo posteriormente, la esposa vino a vivir con su marido a España. No otorgaron capitulaciones matrimoniales. Es preciso determinar la Ley aplicable a los efectos de este matrimonio. Pues bien, la Ley aplicable a los efectos de este matrimonio, incluido naturalmente el régimen económico matrimonial es la Ley cubana, que es la Ley del país de celebración del matrimonio (SAP Zaragoza 28 febrero 2003) 77.

53. Esta Ley puede corresponder a un país con el que el supuesto no presenta ninguna "vinculación sustancial", pues el lugar de celebración del matrimonio puede ser accidental, accesorio o meramente coyuntural, como ocurre con los matrimonios celebrados en lugares exóticos: Bahamas, Bali, Cancún, India, Las Vegas, etc. (A.N. MAKAROV) ${ }^{78}$. La Ley del país de celebración del matrimonio es una "conexión de cierre" prevista para casos vinculados con muchos países, casos en los que no es sencillo detectar una "mayor proximidad" del supuesto con un país. Al menos, es un punto de conexión que concreta, con seguridad jurídica, cuál es la Ley estatal reguladora de los efectos del matrimonio y, en realidad, siempre demuestra una conexión con la intención de los cónyuges. En efecto, éstos no pueden afirmar que el matrimonio no tiene conexión alguna con el país en cuyo territorio se ha celebrado, pues ellos mismos decidieron contraer el enlace en dicho Estado.

54. El precepto se refiere al "lugar" de celebración. De ahí puede deducirse que el legislador ha evitado la aplicación del art. 12.5 CC. De ese modo, cuando el matrimonio se ha celebrado en un Estado plurilegislativo, la Ley aplicable es la Ley que corresponde a la región o estado con Derecho propio en cuyo correspondiente territorio se ha celebrado el enlace matrimonial.

55. Esta conexión es también operativa en casos de Derecho interregional, como bien demuestra la SAP Baleares 11 junio 2014 [causante con vecindad civil ibicenca y régimen económico matrimonial regido por el Derecho civil común español] $]^{79}$.

\section{C) Ámbito de la Ley designada por el art. 9.2 CC}

56. La Ley designada por el art. 9.2 CC sólo regula las "relaciones jurídicas entre los cónyuges". En concreto, dicha Ley regula los siguientes aspectos.

57. En primer lugar, la Ley designada por el art. $9.2 \mathrm{CC}$ rige las relaciones económicas entre los cónyuges y el régimen económico matrimonial. Ello es así incluso en los casos en los que, como sucede en Gran Bretaña, el concepto de "régimen económico del matrimonio" no exista. En otras palabras: las relaciones económicas entre los cónyuges y de éstos frente a terceros se rigen por el art. 9.2 CC y no por la Ley del país de situación de los bienes (art. 10.1 CC), como ha sido correctamente señalado (V. MARTORELl GARCíA). Por otro lado, en los supuestos internacionales, es frecuente que los cónyuges indiquen, en las escrituras de compraventa, que su régimen económico matrimonial es uno u otro. Ahora bien, tales manifestaciones hechas por los cónyuges en dichas escrituras no prueban nada en relación con dicho régimen económico matrimonial. La eficacia probatoria de la escritura pública comprende el contenido

\footnotetext{
77 SAP Zaragoza 28 febrero 2003 [CENDOJ 50297370042003100045].

${ }^{78}$ A.N. MaKarov, "Réfléxions sur l'interpretation des circonstances de rattachement dans les regles de conflit faisant partie d'une convention internationale”, Mélanges offerts a J.Maury, vol. I, París, Dalloz \& Sirey, 1960, pp. 207230.

79 SAP Baleares 11 junio 2014 [CENDOJ 07040370052014100175].
} 
de dicho documento pero no las "cualidades o apreciaciones jurídicas", aspecto que corresponde valorar a los tribunales. El notario se limita a dar fe, respecto de tercero, del hecho que motiva el otorgamiento de la escritura y de la fecha (SAP Barcelona 12 febrero 2013) ${ }^{80}$.

58. En segundo lugar, la Ley designada por el art. 9.2 CC rige también las relaciones personales entre los cónyuges o "efectos personales" del matrimonio. Esta Ley también rige las posibles consecuencias jurídicas de la infracción de estos deberes conyugales extrapatrimoniales.

59. La Ley a la que conduce el art. 9.2 CC regula del mismo modo la disolución del régimen económico matrimonial. La cuestión de decidir si procede o no la disolución del régimen económico matrimonial, tras un divorcio, separación judicial, o declaración de fallecimiento, es un posible efecto jurídico de la declaración de divorcio / separación judicial sobre la economía matrimonial y los bienes de los cónyuges. Por tanto, debe regirse por la Ley que regula la institución afectada, esto es, los efectos del matrimonio, Ley determinada con arreglo al art. 9.2 y 3 CC. No debe aplicarse a esta cuestión ni la Ley que rige el divorcio ni la Lex Fori (con error no exento de confusión: SAP Asturias 6 septiembre 2013 [divorcio entre cónyuges ingleses] $)^{81}$.

60. Esta Ley designada por el art. $9.2 \mathrm{CC}$ rige también la liquidación del régimen económico matrimonial. Esta cuestión queda sujeta a la Ley indicada por el art. 9.2 CC (SAP Barcelona 19 abril 2012 [divorcio entre cónyuges portugueses], SAP Barcelona 22 marzo 2010 [disolución de régimen económico matrimonial de cónyuges polacos $])^{82}$. Solución que se sigue también en otros países (Sent. Cass. Francia 23 mayo 2006) ${ }^{83}$. Los trámites procesales son los fijados en la Ley española (art. 3 LEC) (SAP Barcelona 25 septiembre 2018 [esposos argentinos]; SAP Barcelona 12 septiembre 2018 [cónyuges uruguayos] $)^{84}$.

61. Ciertas consecuencias jurídicas derivadas del matrimonio no quedan sujetas a la Ley designada por el art. 9.2 CC.

Así, el nombre de la mujer casada se rige por la Ley designada por el Convenio de Munich de 5 septiembre 1980, relativo a la ley aplicable a los nombres y apellidos.

Las limitaciones de la capacidad de obrar que puedan derivar del matrimonio para alguno de los cónyuges. Este aspecto se rige por el art. 9.1 CC (STS 17 abril 1956), es decir, por la Ley personal del cónyuge ${ }^{85}$. Ahora bien: el orden público internacional español evitará la aplicación de las limitaciones jurídicas que atenten contra el principio de igualdad entre los cónyuges. En otros casos, como, ad ex., en el supuesto de la incapacidad derivada de la "prohibición veleyana", antigua prohibición que, en defensa de la mujer, la incapacitaba para concluir contratos, y garantizaba el cumplimiento de las obligaciones del marido, se puede recurrir a la "excepción del interés nacional" (art. 13 RR-I y art. 10.8 CC).

La filiación de los hijos matrimoniales es cuestión sujeta a la Ley designada por el art. 9.4 CC. La Ley aplicable a las medidas de protección de los menores, incluida, como es natural, la patria potestad, se determina con arreglo al Convenio de La Haya de 19 octubre 1996 [protección del niño] ${ }^{86}$.

Las donaciones inter-conyugales se regulan por la Ley designada por el Reglamento Roma I de 17 junio 2008 sobre la Ley aplicable a las obligaciones contractuales. En el caso de donaciones incluidas

\footnotetext{
${ }^{80}$ SAP Barcelona 12 febrero 2013 [CENDOJ 08019370182013100046].

${ }^{81}$ SAP Asturias 6 septiembre 2013 [CENDOJ 33044370042013100262].

82 SAP Barcelona 19 abril 2012 [CENDOJ 08019370122012100294]; SAP Barcelona 22 marzo 2010 [CENDOJ 08019370162010100124].

${ }^{83}$ Sentencia de la Cour de Cassation, Chambre civile 1 (Francia), 23 mayo 2006, Bulletin, 2006, I, n. 262 p. 230; https:// beta.legifrance.gouv.fr/juri/id/JURITEXT000007052616.

84 SAP Barcelona 25 septiembre 2018 [ECLI:ES:APB:2018:8937]; SAP Barcelona 12 septiembre 2018 [ECLI:ES:APB:2018:7603].

${ }^{85}$ STS 17 abril 1956 [R.1933].

${ }^{86}$ Convenio relativo a la competencia, la ley aplicable, el reconocimiento, la ejecución y la cooperación en materia de responsabilidad parental y de medidas de protección de los niños, hecho en La Haya el 19 octubre 1996 (BOE núm. 291 de 2 diciembre 2010).
} 
en capitulaciones matrimoniales, el art. $9.3 \mathrm{CC}$ es aplicable (erróneamente: STS 5 junio 2000) ${ }^{87}$. Si se trata de donaciones reguladas por el Derecho de Familia, se aplican dichas normas y no el Reglamento Roma I.

La creación de una sociedad entre los cónyuges se rige por su propia Ley reguladora (Lex Societatis), determinada con arreglo al art. 9.11 CC. No obstante, la Ley que rige los efectos del matrimonio puede establecer limitaciones o prohibiciones a la hora de crear tal sociedad (E. RodRíGuez PINEAU) ${ }^{88}$.

Finalmente, el art. 9.8 CC indica expresamente que "los derechos que por ministerio de la ley se atribuyan al cónyuge supérstite se regirán por la misma ley que regule los efectos del matrimonio, a salvo siempre las legítimas de los descendientes", una solución de "adaptación en sentido amplio", explica A.-L. Calvo Caravaca ${ }^{89}$. Sin embargo, esta disposición sólo es aplicable, hoy día, a los casos de Derecho interregional. En supuestos internacionales, los derechos sucesorios del cónyuge viudo quedan sujetos, de forma radical, advierte I. ANTÓN JUÁREZ, a la Ley que regula la sucesión mortis causa determinada con arreglo al Reglamento sucesorio europeo 650/2012 ${ }^{90}$.

\section{Ley aplicable a los pactos y capitulaciones matrimoniales}

\section{A) Reglas generales}

62. Los cónyuges pueden celebrar entre sí todo tipo de acuerdos, convenios, pactos, o contratos. Desde el punto de vista del Derecho internacional privado, expone A. FusAro, existen varios tipos de acuerdos que pueden celebrar los cónyuges entre sí1 .

En primer lugar, los acuerdos, pactos o contratos que regulan aspectos no relacionados con los efectos del matrimonio. En virtud de estos contratos, los cónyuges pueden acordar, dentro de los límites legales, todo aquello que deseen con efectos legales vinculantes: ventas de bienes, creación de sociedades civiles o mercantiles, donaciones mutuas, etc. Se trata de acuerdos no relacionados con el matrimonio que une a los cónyuges firmantes, acuerdos que no regulan ningún aspecto de las relaciones jurídicas entre cónyuges. Se trata de relaciones patrimoniales no reguladas por el Derecho de Familia. En los casos internacionales, la Ley aplicable a estos contratos se determina con arreglo a las normas de conflicto del Reglamento Roma I de 2008. En el caso de constitución de sociedades por los cónyuges, se aplica la Ley que rige la sociedad creada (arts. 8 y 9 TRLSC).

En segundo término, los acuerdos que regulan efectos personales del matrimonio constituyen contratos que tienen como objeto la reglamentación concreta de los llamados "efectos personales del matrimonio" o "relaciones personales entre los cónyuges". Así, son célebres los casos de personajes famosos que estipulan cuestiones tales como la frecuencia de las relaciones sexuales, el modo en el que se deben llamar uno al otro, la religión que deben observar, las relaciones que pueden tener con terceros, etc. Se trata, en todo caso, de acuerdos y contratos que no están relacionados con la economía matrimonial. En los casos internacionales, la Ley aplicable a estos contratos o acuerdos se fija con arreglo a la Ley estatal a la que conduce el art. 9.2 CC. Dicha Ley decidirá si cabe pactar sobre estos efectos personales del matrimonio y hasta qué límite.

En tercer lugar, los pactos o capitulaciones matrimoniales. Los pactos o capitulaciones matrimoniales son contratos celebrados entre los cónyuges, antes o después del matrimonio y en cuya virtud tales cónyuges establecen, modifican o sustituyen el régimen económico de sus bienes. Son,

${ }^{87}$ STS 5 junio 2000 [CENDOJ 28079110012000102037].

${ }^{88}$ E. Rodríguez Pineau, Régimen económico matrimonial. Aspectos internacionales, Comares, Granada, 2002, pp. 102-105.

${ }^{89}$ A.-L. Calvo Caravaca, "Sucesión hereditaria", en J.D. Gonzélez Campos y otros, Derecho internacional privado parte especial, 1995, pp. 393-422; ID., "La sucesión hereditaria en el Derecho internacional privado español", $R G D, 1986, \mathrm{pp}$. 31033138.

${ }^{90}$ I. ANTÓN JUÁREZ, "Régimen económico matrimonial, derechos sucesorios del cónyuge supérstite y Certificado Sucesorio Europeo: ¿una combinación explosiva?", CDT, 2018, vol. 10, núm. 2, pp. 769-780.

${ }^{91}$ A. FusARo, "Marital contracts, eheverträge, convenzioni e accordi prematrimoniali. Linee di una ricerca comparatistica", La nuova Giurisprudenza civile commentata, 2012, n 7-8, pp. 475-483. También P. GANNAGÉ, "La penétration de l'autonomie de la volonté dans le droit international privé de la famille”, RCDIP, 1992, vol.LXXXI, pp. 425-454. 
por tanto, contratos que regulan el régimen jurídico de la economía matrimonial: las reglas que rigen la propiedad y administración de los bienes de los cónyuges, las aportaciones que los cónyuges o terceras personas deben hacer, en su caso, a la sociedad conyugal o al uso y disfrute común por parte de los miembros de la familia, y disposiciones similares. Tales acuerdos pueden regular el entero régimen económico del matrimonio o sólo un aspecto o parcela del mismo. El régimen jurídico de estos pactos o capitulaciones matrimoniales en DIPr. español se recoge en dos preceptos legales: los párrafos 2 y 3 del art. 9 CC.

63. La naturaleza jurídica de las capitulaciones matrimoniales es, como todo en Derecho, ampliamente discutida. Puede decirse que las capitulaciones matrimoniales constituyen un negocio jurídico singularmente complejo, cuya eficacia se prolonga en el tiempo que dure el matrimonio o hasta que se modifiquen o supriman. Su objeto es crear un estatuto jurídico de los bienes del matrimonio más que crear derechos y obligaciones entre los cónyuges. En general, puede decirse que las capitulaciones matrimoniales constituyen contratos o convenciones matrimoniales sujetas a la condictio juris de la celebración del matrimonio (si nuptiae fuerint secutae) o bien contratos accesorios al matrimonio. Se trata, en definitiva, de un contrato o negocio de Derecho de familia. Es frecuente que en un mismo documento (instrumentum), con asiduidad llamado simplemente "capitulaciones matrimoniales", se contenga no sólo el establecimiento de un régimen económico del matrimonio en cuestión, sino otros pactos o acuerdos interconyugales relativos a los efectos personales del matrimonio y a la disolución del matrimonio. En todo caso, como se ha indicado esta unidad documental no significa unidad jurídica. Por tanto, sólo los acuerdos que afectan a la economía matrimonial deben ser considerados pactos y capitulaciones matrimoniales en el sentido del 9.3 CC. En Derecho Romano no existían capitulaciones matrimoniales y el régimen económico matrimonial era el fijado legalmente. En la Edad Media tampoco eran frecuentes las capitulaciones matrimoniales, puesto que lo que los investigadores jurídicos de la Antigüedad han encontrado son promesas de matrimonio con pago de dote. En las Partidas alfonsinas tampoco se regulan unas auténticas capitulaciones matrimoniales, sino la dote, la escritura de promesa de casamiento, la escritura de obligación de casar, de arras y similares. En realidad, las capitulaciones matrimoniales no aparecen hasta el siglo XVII. En los derechos forales españoles gozan las capitulaciones matrimoniales de honda tradición y se concebían, más bien, como pactos de familia, en los que intervenían no sólo los cónyuges sino también otros integrantes de la familia que realizaban donaciones, otorgaban pactos sucesorios, etc. Fue en particular en Cataluña donde se extendió en gran medida la práctica de celebrar capitulaciones matrimoniales ya en el siglo XVII en todo tipo de familias y no sólo en las que contaban con un patrimonio notable.

64. Los pactos y capitulaciones matrimoniales que regulan la vida económica del matrimonio y celebrados entre los cónyuges están sujetos a la Ley que regula los efectos del matrimonio en general. Dicha Ley se determina con arreglo al art. 9.2 CC. En efecto, la directriz de política jurídica empleada por el legislador en 1990, año de redacción del art. 9.2 y 3 CC hoy en vigor, fue sujetar todos los efectos jurídicos derivados del matrimonio, personales y patrimoniales, a una sola y única Ley estatal reguladora, la Ley designada por el art. 9.2 CC. Por tanto, en los casos internacionales, el art. 9.2 CC determina la Ley aplicable al régimen económico matrimonial, ya existan o no existan acuerdos, pactos o capitulaciones otorgadas por los cónyuges para regular el régimen económico del matrimonio.

\section{B) El art. 9.3 CC: cláusula salvatoria de la validez de los pactos y capitulaciones matrimoniales}

65. Sin perjuicio del carácter general del art. 9.2 CC y de su voluntad de designar la Ley reguladora de todos los efectos del matrimonio en los casos internacionales, incluidos los pactos o capitulaciones matrimoniales, este art. 9.2 CC aparece complementado por una norma específica: el art. 9.3 CC. Se trata de una norma cuya redacción ha suscitado interpretaciones opuestas en la doctrina.

Algunos autores estiman que el art. 9.3 CC señala la Ley reguladora de los pactos o capitulaciones matrimoniales. La redacción legal del precepto no refleja lo que el legislador quiso establecer. Esto 
es, una norma de conflicto de leyes cuyo supuesto de hecho fueran los pactos y capitulaciones matrimoniales y no "la validez de tales pactos y capitulaciones matrimoniales ${ }^{92}$.

Otros expertos jurídicos consideran, por el contrario, que el art. 9.3 CC no indica la Ley reguladora de tales acuerdos, sino que es una norma que ofrece varias Leyes estatales aplicables para "salvar la validez" de los pactos o capitulaciones matrimoniales que pudieran resultar nulos con arreglo a la Ley designada por el art. 9.2 CC. Según esta segunda interpretación, el art. 9.3 CC no es una norma de conflicto standard sino una cláusula salvatoria de la validez de estos pactos o capitulaciones matrimoniales en casos internacionales. Esta tesis sostiene que la "validez" de los pactos y capitulaciones matrimoniales, cuando existan, no se rige por el art. 9.2 CC, que conduce a una sola y única Ley aplicable. Dicha validez se regirá por el art. $9.3 \mathrm{CC}$, precepto que incrementa las posibilidades de considerar válidos los pactos y capitulaciones matrimoniales respecto del art. 9.2 CC, ya que ofrece una serie de puntos de conexión alternativos y hasta cinco posibles Leyes estatales con arreglo a las cuales pueden ser válidos los pactos y capitulaciones matrimoniales. Esta tesis parece preferible. Se ajusta mejor al tenor legal, y desarrolla con exactitud los principios inspiradores fundamentales de la norma central en la materia, el art. 9.2 CC. Esta tesis ha sido apoyada de modo expreso por la DGRN (RDGRN [30a 23 marzo 2018 [capitulaciones y Ley rumana]; RDGRN [34] 13 noviembre 2015 [capitulaciones matrimoniales y cónyuges de nacionalidad portuguesa y marroquí] $)^{93}$.

66. El art. $9.3 \mathrm{CC}$ es una norma de conflicto especial en relación con el art. $9.2 \mathrm{CC}$ y ello puede deducirse con facilidad interpretativa de varios datos.

En primer lugar, se deduce de la colocación sistemática del precepto, pues el art. $9.2 \mathrm{CC}$ recoge, en primer término, la regla general, mientras que, tras ella, el art. $9.3 \mathrm{CC}$ contiene una regla específica, que se enuncia después, tras el art. 9.2 CC.

En segundo lugar, se extrae del supuesto de hecho del art. 9.2 CC, que se presenta como un supuesto de hecho general, que incluye, de modo inequívoco, la precisión de la Ley aplicable a todos los efectos del matrimonio, personas y patrimoniales y por tanto, también a los efectos jurídicos derivados de los pactos y capitulaciones matrimoniales en los casos internacionales. Frente este precepto, el supuesto de hecho del art. 9.3 CC es mucho más reducido: sólo se ocupa de precisar la Ley aplicable a la validez de los pactos y capitulaciones matrimoniales en casos internacionales

En tercer lugar, es perceptible también porque la primera conexión recogida en el art. 9.3 CC es la conexión que recibe y copia del art. 9.2 CC. A partir de ahí, el art. 9.3 CC especializa su respuesta y añade más puntos de conexión. En consecuencia, desde el punto de vista de la técnica jurídica, este art. 9.3 CC no era necesario. Su ausencia no habría provocado laguna legal alguna. Si existe es porque el legislador ha querido alcanzar un resultado que no podía lograr con el art. 9.2 CC.

67. El art. 9.3 CC persigue potenciar la validez de los pactos y capitulaciones matrimoniales que pudieran resultar nulos con arreglo a la Ley estatal determinada en virtud del art. 9.2 CC. Desde este punto de vista, sencillo es detectar que el art. 9.3 CC es una norma de conflicto que permite a las partes posibilidades de selección de la Ley aplicable a los pactos y capitulaciones matrimoniales que no caben en el contexto del art. 9.2 CC. Así los cónyuges de la misma nacionalidad pueden redactar sus pactos y capitulaciones matrimoniales con arreglo a la Ley del país de residencia habitual de cualquiera de ellos y escapar así a su Ley nacional común. También los cónyuges pueden redactar sus pactos y capitulaciones matrimoniales sin necesidad de que éstos consten en documento público. Además, los cónyuges pueden

\footnotetext{
${ }^{92}$ El representante más acreditado de esta corriente es, sin duda, M.A. Amores Conradí en J.D. GonzÁlez Campos y otros, Derecho internacional privado parte especial, Madrid, 1995, pp. 329-354; M.A. AMORES ConRADí, "Las relaciones entre cónyuges en el nuevo Derecho internacional de la familia: valores jurídicos y técnicas de reglamentación”, $A D C, 1987$, pp. 89-138; ID., "La nueva ordenación de la ley aplicable a los efectos del matrimonio", Revista jurídica de Castilla-La Mancha, núms. 11-12, enero-agosto 1991, pp. 44-51; M.A. Amores ConRAdí, "Art. 9.2 y 3 CC", AA.VV, Comentarios al Código Civil y a las Compilaciones forales, dirigidos por M. Albaladejo y S. Díaz Alabart, tomo I, vol.II, $2^{\text {a }}$ ed., Ed.Revista de Derecho privado / Edersa, Madrid, 1995, pp. pp. 181-205; ID., "Régimen económico matrimonial (Derecho internacional privado)", en VV.AA., Enciclopedia jurídica básica, dirigida por A. Montoya Melgar, Ed.Civitas, Madrid, 1995, pp. 5692-5693.

${ }^{93}$ RDGRN 5 marzo 2018 [BOE núm. 69 de 20 marzo 2018]; RDGRN [34ㄹ] 13 noviembre 2015 [JUR 2016/115973].
} 
también redactar sus pactos y capitulaciones matrimoniales después de la celebración del matrimonio. $\mathrm{El}$ art. 9.3 CC existe, por tanto, para aumentar las posibilidades de validez de los pactos y capitulaciones matrimoniales, pues el art. 9.2 CC podría llevar, con cierta facilidad, a considerar que unos concretos pactos y capitulaciones matrimoniales son nulos con arreglo a la Ley a la que conduce dicho art. 9.2 CC.

68. Resulta preciso seguir un enfoque analítico de estas dos tesis para ponderar sus ventajas e inconvenientes.

$\left.1^{\circ}\right)$ Como antes se ha avanzado, ciertos autores consideran que el art. $9.3 \mathrm{CC}$ constituye una norma de conflicto totalmente independiente del art. 9.2 CC y que ofrece puntos de conexión alternativos que señalan la Ley reguladora de estos pactos o capitulaciones matrimoniales. De este modo, la Ley aplicable a los pactos o capitulaciones matrimoniales es la Ley que rige los efectos del matrimonio ex art. 9.2 CC o bien la Ley nacional o de la residencia habitual de cualquiera de las partes al tiempo del otorgamiento. Esta lectura simplifica la comprensión del precepto. Sin embargo, presenta ciertos inconvenientes: (a) La letra del art. 9.3 CC no colabora pues el supuesto de hecho de dicha norma de conflicto no está constituido por los "pactos o capitulaciones matrimoniales" sino por la "validez" de tales acuerdos. La norma es clara al respecto; (b) El enfoque del art. 9.2 CC juega también en contra de esta interpretación. Este art. 9.2 CC tiene como objetivo asegurar la unidad de la Ley aplicable a todos los efectos del matrimonio, existan o no existan "pactos o capitulaciones matrimoniales". Esta lectura del art. 9.3 CC rompe la unidad legal perseguida por el legislador; (c) Existen otras normas del DIPr. español que tienen como supuesto de hecho la "validez" de un acto jurídico. Así el art. 9.8 CC [ley aplicable a la sucesión mortis causa] precisa que la Ley reguladora de la sucesión por causa de muerte es la Ley nacional del causante en el momento de su fallecimiento, pero que las disposiciones hechas en testamento y los pactos sucesorios ordenados conforme a la Ley nacional del testador o del disponente en el momento de su otorgamiento "conservarán su validez". Es decir que la ley que rige la sucesión mortis causa es la Ley nacional del causante en el momento de su fallecimiento, pero si con arreglo a dicha Ley los testamentos y pactos sucesorios no resultaren válidos, entonces todavía pueden ser considerados válidos si se ajustan a la Ley del país cuya nacionalidad ostentaba el testador en el momento de su otorgamiento. El objetivo de esta disposición es "salvar la validez" de testamentos y pactos sucesorios que serían nulos y para ello, el legislador añade una nueva Ley aplicable a la validez de tales actos jurídicos: la Ley nacional del testador o del disponente en el momento de su otorgamiento. La estructura de este art. 9.8 CC es la misma que la que muestra el art. 9.3 CC. Por ello, es más razonable pensar que el legislador español ha seguido la misma línea en el art. 9.8 $\mathrm{CC}$ y en el art. 9.3 CC, de modo que este precepto señala, exclusivamente, la Ley aplicable a la "validez" de los pactos o capitulaciones matrimoniales y no la Ley aplicable a los pactos o capitulaciones matrimoniales; (d) No existen en los países occidentales normas de conflicto que señalen la Ley aplicable a los pactos o capitulaciones matrimoniales. En los países europeos existen normas de conflicto que precisan la Ley aplicable al régimen económico matrimonial pero no la Ley aplicable a los pactos o capitulaciones matrimoniales. Ello invita a pensar que es difícil aceptar que el legislador español haya sido tan original y haya sido el único de su entorno que ha formulado una norma de conflicto que fija la Ley aplicable a estos pactos o capitulaciones matrimoniales; (e) La posición en la que aparecen las conexiones en el art. 9.3 CC ofrece también una poderosa clave de comprensión del sistema. La primera Ley aplicable que debe regular la validez de los pactos o capitulaciones matrimoniales es la Ley a la que remite el art. 9.2 CC. Posteriormente, el legislador ofrece otras leyes con arreglo a las cuales se puede salvar la validez de estos pactos o capitulaciones matrimoniales: la Ley de la nacionalidad o de la residencia habitual de cualquiera de las partes al tiempo del otorgamiento. Por tanto, parece claro que el art. 9.3 CC opera como una excepción al art. 9.2 CC en cuya virtud se trata de salvar la validez de 
los pactos o capitulaciones matrimoniales que serían considerados no válidos con arreglo a la Ley reguladora de los efectos del matrimonio determinada por el art. 9.2 CC. Por todas estas razones, esta interpretación no parece compartible, mientras que la tesis que sostiene que el art. 9.3 CC es una cláusula salvatoria de la validez de los pactos o capitulaciones matrimoniales se muestra más sólida.

$2^{\circ}$ ) Como antes también se ha indicado, una segunda lectura del art. 9.3 CC sostiene que el objetivo de este precepto no es establecer la "Ley aplicable" a los pactos y capitulaciones matrimoniales. Eso ya lo hace el art. 9.2 CC con meridiana claridad. El objetivo real del art. 9.3 CC es bien diferente. Este precepto opera como "cláusula salvatoria" de los pactos y capitulaciones matrimoniales que pudieran resultar nulos con arreglo a la Ley estatal determinada en virtud del art. $9.2 \mathrm{CC}$. Con otras palabras, puede afirmarse que la "validez" de los pactos y capitulaciones matrimoniales, cuando existan, no se rige por el art. $9.2 \mathrm{CC}$, que conduce a una sola y única Ley aplicable. Dicha validez se regirá por el art. $9.3 \mathrm{CC}$, precepto que incrementa las posibilidades de considerar válidos los pactos y capitulaciones matrimoniales respecto del art. 9.2 CC, ya que ofrece una serie de puntos de conexión alternativos y hasta cinco posibles Leyes estatales con arreglo a las cuales pueden ser válidos los pactos y capitulaciones matrimoniales. En efecto, el art. 9.3 CC indica que los pactos o capitulaciones matrimoniales serán válidos cuando sean conformes a la Ley que rija los efectos del matrimonio ex art. 9.2 CC, pero también cuando se ajusten a la Ley de la nacionalidad o de la residencia habitual de cualquiera de las partes al tiempo del otorgamiento. Es decir: el art. 9.3 CC "añade" a la Ley que rige los efectos del matrimonio, otras posibles Leyes estatales que pueden aplicarse para solventar la cuestión de la "validez" de las capitulaciones matrimoniales. Si el art. 9.3 CC no existiera, dicha validez habría que juzgarla, exclusivamente, con arreglo a una sola Ley, la Ley que rige los efectos del matrimonio ex art. 9.2 CC. De este modo, el art. 9.3 CC favorece la "validez" de los pactos o capitulaciones matrimoniales en los casos internacionales (RDGRN [5'] 25 septiembre 2007 [capitulaciones otorgadas por española e italiano ante Notario italiano] $)^{94}$. El art. 9.3 CC determina, por tanto, la Ley aplicable a la "validez" de tales pactos o capitulaciones matrimoniales, y nada más. El resto de cuestiones jurídicas relativas al régimen económico del matrimonio se rigen por la Ley designada a través del art. 9.2 CC. Naturalmente, cuanto más extensos y detallados sean los pactos y capitulaciones matrimoniales, más amplio será el ámbito de la Ley designada por el art. 9.3 CC y más restringido será el ámbito de la Ley designada por el art. 9.2 CC. Y viceversa. Esta lectura del art. 9.3 CC ha sido aceptada de manera expresa por la DGRN (RDGRN [34'] 13 noviembre 2015 [capitulaciones matrimoniales y cónyuges de nacionalidad portuguesa y marroquí]: "y en cuanto a las capitulaciones matrimoniales, el apartado 3 del art. 9 CC no determina una Ley aplicable, sino que señala las distintas leyes que pueden ser empleadas como parámetros de validez, de manera que los pactos o capitulaciones sobre régimen económico de matrimonio serán válidos siempre que sean conformes bien a la Ley que rija los efectos del matrimonio (en este caso la Ley española, como se ha visto), bien a la Ley de la nacionalidad (portuguesa o marroqui) o bien a la de la residencia habitual de las partes al tiempo del otorgamiento (nuevamente la española en esta ocasión). En consecuencia (....) , la Ley española es perfectamente aplicable al caso (...) la validez de las capitulaciones no depende de su constancia en el Registro civil, teniendo la indicación registral carácter voluntario y a efectos únicamente de la publicidad a terceros" $)^{95}$. En conclusión, para poder indicar las capitulaciones matrimoniales en el Registro Civil español es preciso acreditar la validez de las mismas y para ello se acude al art. 9.3 CC.

\footnotetext{
94 RDGRN [5 25 septiembre 2007 [JUR 2007/315032].

95 RDGRN [34 13 noviembre 2015 [JUR 2016/115973].
} 


\section{C) Caracteres del art. 9.3 CC}

\section{a) Acuerdos interconyugales cubiertos por el precepto}

69. El art. 9.3 CC indica: "Los pactos o capitulaciones por los que se estipule, modifique o sustituya el régimen económico del matrimonio serán válidos cuando sean conformes bien a la ley que rija los efectos del matrimonio, bien a la ley de la nacionalidad o de la residencia habitual de cualquiera de las partes al tiempo del otorgamiento".

70. La expresión "pactos y capitulaciones matrimoniales" es un "concepto amplio propio del DIPr." que se emplea como supuesto de hecho del art. 9.3 CC. Se trata de una expresión amplia: "pactos o capitulaciones por los que se estipule, modifique o sustituya el régimen económico del matrimonio", sobre la que diversas observaciones son necesarias.

La expresión "pactos o capitulaciones" comprende todo acuerdo entre los cónyuges relativo a la "economía matrimonial". Nótese la utilización de la conjunción disyuntiva "o" en el precepto. Significa ello que los "pactos" a los que se refiere el precepto son equivalentes a las "capitulaciones matrimoniales". Equivalentes en cuanto a su función, que también consta expresamente en el art. 9.3 CC. Es decir, esta norma determina la Ley aplicable a todo acuerdo entre los cónyuges que se dirija, exclusivamente, a regular la economía del matrimonio, acuerdos "por los que se estipule, modifique o sustituya el régimen económico del matrimonio". Si la norma hubiera empleado la conjunción copulativa "y" (= "pactos y capitulaciones matrimoniales") entonces y sólo entonces el art. 9.3 CC sería aplicable a todo acuerdo entre los cónyuges regule o no la economía del matrimonio. Sin embargo, como se ha visto, ello no es así. Así, el precepto no se aplica a unos acuerdos entre cónyuges que establecen reglas para la liquidación de los gananciales, porque tales acuerdos no establecen ni modifican el régimen económico del matrimonio (RDGRN [46a] 3 marzo 2017 [capitulaciones matrimoniales]). Por tanto, el art. 9.3 CC fija la Ley aplicable a la validez de los siguientes acuerdos: (a) Las "capitulaciones matrimoniales" en el sentido del art. $1325 \mathrm{CC}$, esto es, las capitulaciones matrimoniales en "el sentido español" (= un acuerdo interconyugal que, desde los ojos del Derecho civil español, puede y debe ser considerado como "capitulaciones matrimoniales"). Así, los acuerdos entre los cónyuges firmados en documento privado o meramente orales no pueden ser calificado como "capitulaciones matrimoniales", porque para el Derecho español sólo son tales los que constan en escritura pública (arts. 1325 y 1327 CC); (b) Cualquier otro tipo de pacto o negocio celebrado entre los cónyuges y que regule su "economía matrimonial", con total independencia del nombre (nomen juris) que reciba con arreglo a un Derecho extranjero o del nombre o título que las partes hayan dado a su negocio (SAP Baleares 9 junio 2006) ${ }^{96}$. Este es el aspecto más relevante de la dicción literal del supuesto de hecho del art. 9.3 CC, su virtualidad para incluir en el mismo los acuerdos interconyugales que regulan la economía del matrimonio pero que no podrían ser considerados "capitulaciones matrimoniales" según el Derecho civil español. De ese modo se evitan los complejos problemas de calificación característicos del DIPr. En efecto, si el art. 9.3 CC sólo se refiriese a la Ley aplicable a las "capitulaciones matrimoniales", sería difícil aplicarlo a la validez de acuerdos interconyugales que regulan la economía del matrimonio pero que no son, técnicamente y desde el prisma del Derecho español, "capitulaciones matrimoniales". En todo caso, el supuesto concreto, el acuerdo entre los cónyuges relativo a la economía de su matrimonio debe ser "internacional". De ese modo, la posibilidad de ajustar sus capitulaciones o pactos a las Leyes a las que se refiere el art. 9.3 CC sólo es operativa si el supuesto presenta "elementos extranjeros" (con confusión y sin aludir al art. 9.3 CC: RDGRN [9a 3 octubre 2011 [matrimonio consular islámico celebrado en España entre contrayentes marroquíes]) ${ }^{97}$.

Sin embargo, no son "pactos o capitulaciones matrimoniales" y quedan excluidos de este art. 9.3 CC los siguientes acuerdos: (a) Pactos entre los cónyuges sin relación con la "economía matrimonial", como por ejemplo, las donaciones entre cónyuges al margen de capitulaciones (erróneamente: STS 5 junio 2000), la creación de una sociedad civil o mercantil entre los cónyuges, los pactos para regular

\footnotetext{
${ }^{96}$ SAP Baleares 9 junio 2006 [CENDOJ 07040370042006100244].

${ }^{97}$ RDGRN [9' 3 octubre 2011 [JUR 2012/301410].
} 
un posible divorcio o separación entre los cónyuges, los pactos en cuya virtud los cónyuges regulan sus obligaciones personales derivadas del matrimonio, como la prestación de ayuda en el hogar, las relaciones sexuales dentro o fuera del matrimonio y otras ${ }^{98}$; (b) Pactos entre los cónyuges que sirven para fijar el "lugar de residencia habitual común inmediatamente posterior a la celebración del matrimonio"; (c) Las manifestaciones de los cónyuges en escritura notarial cuya única finalidad es confirmar el régimen económico matrimonial determinado por la Ley (RDGRN [1 $1^{\mathrm{a}} 5$ mayo 2011 [escritura de manifestaciones en favor del régimen económico de separación de bienes recogido en el Código de Familia de Cataluña], RDGRN [5 $5^{\mathrm{a}}$ 22 noviembre 2005) ${ }^{99}$; (d) Los acuerdos de los cónyuges para regular un divorcio o separación conyugal en el futuro o en el presente; (e) Acuerdos sobre la liquidación del régimen económico matrimonial; (f) Pactos relativos a la sucesión mortis causa entre los cónyuges. El art. 9.3 CC no es aplicable a estos acuerdos (RDGRN [3 $\left.3^{\mathrm{a}}\right] 8$ enero 2004) ${ }^{100}$; (g) Pactos sobre liquidación de los gananciales. Estos pactos no establecen ni modifican el régimen económico del matrimonio (RDGRN [46 $\left.{ }^{\mathrm{a}}\right] 3$ marzo 2017 [capitulaciones matrimoniales]) ${ }^{101}$. En un mismo documento (instrumentum) pueden constar capitulaciones matrimoniales y otros acuerdos o pactos de carácter personal o patrimonial, pero tales otros acuerdos no forman parte de las capitulaciones matrimoniales y se rigen por sus propias disposiciones legales. Como indica C. Martinez de AguirRe y Aldaz, en el contenido estrictamente patrimonial de los pactos o capitulaciones matrimoniales deben distinguirse dos tipos de disposiciones ${ }^{102}$ : (i) Atribuciones capitulares. Se trata de donaciones y entregas de bienes y activos que un cónyuge hace al otro, o que hace a la sociedad conyugal, o que terceras personas realizan a uno o a los dos cónyuges con el objetivo de ayudar al levantamiento de las cargas del matrimonio ya se haya celebrado éste o deba aún celebrarse. Tales atribuciones capitulares no modifican el régimen económico matrimonial. No regulan la economía del matrimonio y por tanto están excluidas del art. $9.3 \mathrm{CC}$; (ii) Estipulaciones capitulares. Son éstas las que disponen de un contenido normativo que regulará la economía de la familia. La Ley que rige dichas disposiciones se determina con arreglo a los arts. 9.2 y $9.3 \mathrm{CC}$.

\section{b) Puntos de conexión alternativos y autonomía conflictual oculta}

71. El art. 9.3 CC contiene puntos de conexión alternativos, con el objetivo de favorecer la validez de los pactos o capitulaciones matrimoniales en los casos internacionales (RDGRN [5 $5^{\mathrm{a}} 25$ septiembre 2007 [capitulaciones otorgadas por española e italiano ante Notario italiano]) ${ }^{103}$. En efecto: tales pactos o capitulaciones matrimoniales serán válidos si se redactan con arreglo a lo dispuesto en cualquiera de estas Leyes: $1^{\circ}$ ) Ley que rige los efectos del matrimonio según el art. $9.2 \mathrm{CC} ; 2^{\circ}$ ) Ley de la nacionalidad o de la residencia habitual de cualquiera de los cónyuges al tiempo del otorgamiento del pacto. Por ello, en teoría, pueden ser hasta cinco los Derechos nacionales distintos que pueden hacer válidos los pactos económicos entre los cónyuges. Para que tales pactos puedan ser declarados nulos o ineficaces, ninguno de los ordenamientos a los que se remite el art. $9.3 \mathrm{CC}$ debe considerar válidos dichos pactos.

72. El art. 9.3 CC sigue, claramente, un Better-Law Approach. El art. $9.3 \mathrm{CC}$ es una "norma de conflicto materialmente orientada". La selección de la concreta Ley aplicable a la validez de las capitulaciones matrimoniales depende del contenido del Derecho estatal aplicable y del resultado de la aplicación del mismo a unos concretos pactos o capitulaciones matrimoniales. Si los efectos de un matrimonio entre iraquí y española se rigen por la Ley española ex art. 9.2 CC, y los capítulos son nulos con arreglo a la Ley española, la validez de tales capitulaciones quedará sujeta a la Ley iraquí sólo si dicha

\footnotetext{
${ }^{98}$ STS 5 junio 2000 [CENDOJ 28079110012000102037].

99 RDGRN [1 5 a mayo 2011 [JUR 2012/147877]; RDGRN [5 ${ }^{\mathrm{a}}$ 22 noviembre 2005 [R. 2006/224].

${ }^{100}$ RDGRN [3 ${ }^{\mathrm{a}}$ ] 8 enero 2004 [R. 2004/2371].

${ }^{101}$ RDGRN [46 3 ] marzo 2017 [BIMJ n. 2206 marzo 2018].

102 C. Martínez de Aguirre Aldaz, "La economía del matrimonio. Capitulaciones matrimoniales", en C. Martínez de AguiRRE Aldaz y otros, Curso de Derecho Civil (IV) Derecho de Familia, Colex, Madrid, 2007, pp. 197-222.

${ }^{103}$ RDGRN [5 ${ }^{\mathrm{a}}$ 25 septiembre 2007 [JUR 2007/315032].
} 
Ley considera, por el contrario, que las capitulaciones son válidas. Por tanto, la aplicación de la Ley iraquí depende de su contenido material y del resultado que la aplicación de dicho ordenamiento jurídico produce en el caso concreto. La selección de la Ley aplicable a la validez de los pactos o capitulaciones matrimoniales depende, en el art.9.3 CC, de datos y circunstancias materiales y no sólo de la conexión o proximidad del caso con uno un otro Estado.

73. Al determinar la Ley reguladora de la validez de los pactos o capitulaciones matrimoniales este precepto persigue favorecer la validez sustancial de tales acuerdos. Éstos serán nulos sólo si ninguna de las Leyes recogidas en el art. 9.3 CC considera que tales capitulaciones son válidas (RDGRN 23 noviembre 2006 [acuerdo prenupcial entre cónyuge español y pakistaní firmado en Pakistán], RDGRN [5 $\left.5^{\mathrm{a}}\right] 25$ septiembre 2007 [capitulaciones otorgadas por española e italiano ante Notario italiano]) ${ }^{104}$.

74. El art. 9.3 CC faculta a los cónyuges para redactar sus pactos o capitulaciones matrimoniales válidamente con arreglo a cualquiera de las Leyes estatales a las que se refiere el art. 9.3 CC. Por tanto, existe una "autonomía de la voluntad conflictual" de los cónyuges, si bien limitada y oculta. En realidad, el art. 9.3 CC concede a los cónyuges la posibilidad de elegir la Ley estatal con arreglo a la cual desean redactar sus pactos para que éstos resulten válidos (SAP Madrid 10 julio 2007 [capitulaciones otorgadas en Holanda y régimen de comunidad de mobiliario del Derecho holandés] $)^{105}$. Un resultado idéntico al que ahora produce el art. 9.3 CC se alcanzaría si el precepto se expresara en términos similares a éstos: "los cónyuges podrán ajustar la validez de sus pactos o capitulaciones matrimoniales a la Ley que rige los efectos del matrimonio, a la ley nacional de cualquiera de ellos o a la ley de la residencia habitual de cualquiera de ellos".

75. Las Leyes susceptibles de elección por los cónyuges y que ofrece el art. $9.3 \mathrm{CC}$ son limitadas. Los cónyuges no pueden elegir libremente la Ley estatal que deseen para que regule la validez de sus pactos o capitulaciones matrimoniales. Existe una "rosa de Leyes estatales" y los cónyuges deben seleccionar aquella Ley estatal con arreglo a la que desean redactar sus pactos o capitulaciones matrimoniales. Si los cónyuges redactan sus pactos o capitulaciones matrimoniales de modo que son válidos exclusivamente con arreglo a una Ley estatal no incluida en la "rosa de Leyes" contemplada en el art. 9.3 CC, entonces tales pactos o capitulaciones matrimoniales serán nulos. Las Leyes que el art. 9.3 CC ofrece como parámetros legales para "hacer válidos" los pactos o capitulaciones matrimoniales son la Ley que rige los efectos del matrimonio ex art. 9.2 CC, así como la Ley de la nacionalidad o de la residencia habitual de cada contrayente en el momento de redacción de las capitulaciones. Por tanto, el art. 9.3 CC ofrece hasta un máximo de cinco Leyes estatales. Cuanto "más internacional" es el matrimonio, más Leyes estatales podrán elegir los cónyuges para regir sus pactos o capitulaciones matrimoniales. Esta limitación de Leyes elegibles a las cinco máximas posibles carece, en realidad, de una razón de ser sólida y clara. No existe ningún argumento definitivo para impedir a los cónyuges la redacción de sus pactos o capitulaciones matrimoniales con arreglo a la Ley estatal que prefieran. Las capitulaciones son contratos. En relación a los contratos internacionales, las partes pueden elegir la Ley estatal que mejor se acomode a sus intereses (art. 3 Reg. Roma I). Así, en el caso de que cónyuges de la misma nacionalidad redacten unos pactos o capitulaciones matrimoniales que sólo resultan válidos con arreglo a la Ley del país de celebración del matrimonio, tales acuerdos son nulos. En efecto, la Ley del país de celebración del matrimonio no está incluida en la rosa de Leyes recogida en el art. 9.3 CC. Sin embargo, estos acuerdos son contratos. Resulta paradójico que los contratantes puedan elegir como Ley reguladora de su contrato la Ley del país de su celebración pero no puedan elegir como Ley reguladora de sus pactos o capitulaciones matrimoniales esa misma Ley, la Ley del país de celebración de tales pactos.

76. El art. 9.3 CC se refiere, con acierto, a las "partes". En efecto, los cónyuges pueden redactar sus pactos o capitulaciones matrimoniales antes de contraer matrimonio, caso en el que todavía no son

\footnotetext{
${ }^{104}$ RDGRN 23 noviembre 2006 [JUR 2008/112558]; RDGRN [5ª 25 septiembre 2007 [JUR 2007/315032].

105 SAP Madrid 10 julio 2007 [CENDOJ 28079370222007100531].
} 
"cónyuges" sino "partes" (J. RodRíGuez RodRigo). Por otra parte, es relativamente frecuente que otros sujetos, -padres, terceros, otros parientes-, participen en las capitulaciones matrimoniales, en las que pueden incluir donaciones por razón de matrimonio u otras transmisiones patrimoniales. Tales sujetos no son "partes" a efectos del art. 9.3 CC. No pueden elegir la Ley aplicable a estos pactos o capitulaciones matrimoniales porque no participan en el diseño de la economía matrimonial que consta en los pactos o capitulaciones matrimoniales.

\section{c) Capitulaciones redactadas con arreglo a varias leyes estatales (dépeçage)}

77. Muy controvertida en la doctrina resulta la posibilidad de considerar válidos los pactos o capitulaciones matrimoniales que se ajustan a varias de las Leyes recogidas en el art. 9.3 CC. Es decir, se trata de estimar válidos unos pactos o capitulaciones matrimoniales porque algunas de sus disposiciones se ajustan a una de las Leyes recogidas en el art. 9.3 CC y otras se acomodan y son válidas con arreglo a otra de las Leyes a las que se refiere dicho precepto. Los pactos o capitulaciones matrimoniales se dividen, así, en "partes" o "segmentos" que se ajustan a Leyes diferentes, todas ellas contempladas en el art. 9.3 CC. A favor de este fraccionamiento puede indicarse que el art. $9.3 \mathrm{CC}$ persigue favorecer la validez de estos pactos o capitulaciones matrimoniales, que permite unificar la Ley aplicable a los bienes inmuebles y la Ley aplicable al régimen económico matrimonial que recae sobre tales inmuebles, que el art. 9.3 CC no prohíbe esta elección múltiple de la Ley aplicable, y que, entre otros factores, es una opción permitida en otros sistemas de DIPr. (art. 15 EGBGB Alemania). En contra también muchos argumentos existen: (a) Este favor, que, es cierto, constituye un muy sólido principio vertebrador del art. 9.3 CC, no es ilimitado ni incondicional. Tiene límites muy claros trazados por el legislador español; (b) La dicción de la norma no ayuda pues es claro que se refiere siempre a "la ley" que rija los efectos del matrimonio y a "la ley" de la nacionalidad o de la residencia habitual de cualquiera de las partes. Esto es, siempre se expresa en singular, por lo que parece que el legislador tuvo in mente siempre la misma idea: que las partes podían ajustar la validez de sus capitulaciones a una sola de las Leyes indicadas en el art. 9.3 CC. No pueden, por tanto, "trocear" sus capitulaciones y someter unos capítulos a una Ley y otros a otra Ley estatal distinta; (c) En ningún momento el precepto admite que las partes puedan ajustar ciertos capítulos a una Ley de las nombradas en el art. 9.3 CC y otros capítulos a otra Ley estatal diferente. Existen preceptos legales que sí admiten expresamente esta posibilidad (art. 3.1 in fine RR-I). Por tanto, puede sostenerse que cuando el legislador lo ha querido admitir, así lo ha expresado y que cuando calla, es porque niega la posibilidad de dépeçage legal del contrato; (d) Aunque resulta recurrente en la doctrina afirmar que el art 9.3 CC admite la autonomía de la voluntad conflictual, en realidad, ello no es así. El precepto citado en ningún momento otorga a los cónyuges la posibilidad de elegir la Ley aplicable a los pactos y capitulaciones matrimoniales, como tampoco lo hace el art. $11 \mathrm{CC}$ en relación con la Ley aplicable a la forma de los actos. Las normas de conflicto con puntos de conexión simplemente alternativos no conceden a las partes la facultad de elección de Ley sino que aumentan las posibilidades de validez del acto. Por tanto, no puede afirmarse que el dépeçage jurídico de los pactos y capitulaciones matrimoniales es consecuencia directa de la autonomía de la voluntad que vertebra el art. 9.3 CC, pues non causa pro causa (= el hecho de que existan varias conexiones en el precepto no es consecuencia de la previa admisión de la autonomía de la voluntad conflictual de los cónyuges). En conclusión, puede sostenerse que, como línea de principio, no parece que deba admitirse que los cónyuges elijan Leyes estatales diferentes para regular distintos aspectos de sus capitulaciones matrimoniales (dépeçage). Pueden ajustar sus pactos o capitulaciones matrimoniales a una sola de las Leyes recogidas en el art. 9.3 CC.

\section{d) Cambio del contenido de los pactos o capitulaciones matrimoniales}

78. Los cónyuges pueden "alterar" el régimen jurídico de sus relaciones patrimoniales, en todo o en parte. Basta con que una de las Leyes a las que remite el art. $9.3 \mathrm{CC}$ permita tal cambio. El hecho de que la Ley reguladora del régimen económico matrimonial determinada con arreglo al art. 9.2 CC 
no permita que los cónyuges alteren dichas capitulaciones, es irrelevante, siempre que una de las Leyes designadas por el art. 9.3 CC permita la modificación de las capitulaciones anteriores o el cambio o alteración del régimen legal antes aplicable a la economía matrimonial.

\section{e) Reenvío y art. 9.3 CC}

79. El reenvío de retorno (art. 12.2 CC) no es un mecanismo obligatorio. Debe utilizarse para potenciar valores jurídicos dignos de protección según el Derecho español y debe respetar el principio inspirador del art. $9.3 \mathrm{CC}$, norma de conflicto en la materia. El principio básico de dicha norma es la preservación de la validez legal de fondo de los pactos o capitulaciones matrimoniales (favor contractus). De ello se extraen varias consecuencias relevantes: $1^{\circ}$ ) El reenvío de retorno puede admitirse si produce como resultado final la validez de las capitulaciones matrimoniales; $2^{\circ}$ ) El reenvío de retorno debe rechazarse si hace nulos o ineficaces los pactos o capitulaciones matrimoniales, porque vulnera un principio inspirador del art. 9.3 CC, esto es, su propósito de favorecer la validez de los pactos o capitulaciones matrimoniales.

80. El art. 9.3 CC sólo determina la Ley aplicable a la "validez" de fondo de los pactos o capitulaciones matrimoniales (RDGRN [5 $5^{\mathrm{a}}$ ] 25 septiembre 2007 [capitulaciones otorgadas por española e italiano ante Notario italiano] $)^{106}$. El art. 9.3 CC no precisa la Ley aplicable al régimen económico matrimonial. El art. 9.3 CC tampoco determina la Ley aplicable a los pactos o capitulaciones matrimoniales. En realidad, diversos aspectos jurídicos relacionados con los pactos o capitulaciones matrimoniales escapan al art. 9.3 CC: (a) La capacidad requerida para otorgar pactos y capitulaciones matrimoniales; (b) El consentimiento para otorgar dichos pactos; (c) La forma de los pactos o capitulaciones matrimoniales; (d) Todos los aspectos legales relativos a los pactos o capitulaciones matrimoniales que sean distintos a la mera "validez" de los mismos, tales como su aplicación práctica, su interpretación o la liquidación del régimen económico matrimonial establecido en virtud de los pactos o capitulaciones matrimoniales del os que se trate.

\section{f) Pactos de elección de Ley contenidos en capitulaciones matrimoniales}

81. En ocasiones, los cónyuges redactan sus pactos y capitulaciones matrimoniales e incorporan a los mismos ciertas cláusulas que constituyen auténticos "acuerdos de elección de la Ley aplicable", observa K. SIEHR ${ }^{107}$. En tales "acuerdos de elección de la Ley aplicable" los cónyuges someten sus pactos o capitulaciones matrimoniales a una concreta Ley estatal, como suele hacerse en los contratos internacionales. Ejemplo: en unas capitulaciones matrimoniales entre cónyuges españoles con residencia habitual en Berlín se contiene una cláusula que expresa: "estas capitulaciones se regirán por la Ley alemana". Sobre la validez de estos pactos de elección de Ley aplicable al régimen económico matrimonial y a las capitulaciones matrimoniales cabe introducir ciertas observaciones.

En primer lugar, el art. 9.3 CC no regula estos acuerdos de elección de Ley. No los prohíbe pero tampoco los admite de modo expreso. La doctrina mayoritaria entiende que tales acuerdos de "elección de Ley" deben admitirse, deben considerarse válidos y posibles y deben surtir efectos. Varios argumentos apoyan esta tesis favorable a estos acuerdos de elección de Ley: (a) Si se permite a los cónyuges, en Derecho material español, regular a voluntad sus relaciones patrimoniales, es lógico que se permita que en DIPr. puedan elegir la Ley aplicable al régimen económico matrimonial, buen argumento defendido con ahínco por M.A. AmORES ConRADí1 ${ }^{108}$; (b) El supuesto de hecho amplísimo del art. $9.3 \mathrm{CC}$ cubre todo

\footnotetext{
${ }^{106}$ RDGRN [5a] 25 septiembre 2007 [JUR 2007/315032].

${ }^{107}$ K. SIEHR, "Divorce of muslim marriages in secular courts", Vers de nouveaux équilibres entre ordres juridiques (Mélanges en l'honneur de Hélème Gaudemet-Tallon), Dalloz, París, 2008, pp. 809 y ss.

${ }^{108}$ M.A. Amores Conradí, “Art. 9.2 y 3 CC”, AA.VV, Comentarios al Código Civil y a las Compilaciones forales, dirigidos
} 
tipo de "acuerdos" que afectan a la economía matrimonial, lo que debe incluir también los "pactos de elección de Ley" aplicable a las capitulaciones matrimoniales, como bien expone J.M. FonTANELLAS Morell en su magnífico trabajo ${ }^{109}$. En verdad, un acuerdo de elección de Ley en cuya virtud los cónyuges indican que sus capitulaciones matrimoniales quedan sujetas al Derecho del Estado X, es una disposición que forma parte de las capitulaciones matrimoniales o que, incluso, puede considerarse, sin temor, como un pacto o capitulación matrimonial en sí mismo. Por tanto, son posibles y son válidos si se ajustan al art. 9.3 CC. La jurisprudencia también acepta estos pactos de elección de Ley en los capítulos (SAP Barcelona 3 abril 2012 [cónyuges holandeses]) ${ }^{110}$.

En segundo lugar y a diferencia de lo que dispone el Reglamento Roma I o el art. 10.5 CC en relación con los contratos internacionales, y como se ha indicado, el art. 9.3 CC no faculta a las partes para elegir la Ley aplicable a los contratos matrimoniales, pactos o capitulaciones matrimoniales. Admitir la posibilidad de estos acuerdos de elección de Ley es posible pero siempre dentro de su marco legal, esto es, en el contexto del art. 9.3 CC. Por tanto, estos acuerdos de elección de Ley aplicable a los pactos o capitulaciones matrimoniales deben considerarse como "acuerdos de puntualización de la Ley aplicable" en el marco del art. 9.3 CC. De ese modo, los cónyuges pueden señalar que han redactado sus capítulos con arreglo a la Ley elegida por ellos mismos, siempre que se trate de una Ley de las contempladas por el art. 9.3 CC. Debe quedar claro que el alcance jurídico de estos acuerdos de elección de Ley es limitado porque es el mismo art. 9.3 CC el que los limita. Esta limitación operativa debe entenderse en tres sentidos: (i) La Ley elegida por los cónyuges sólo regula la "validez de fondo" de los pactos o capitulaciones matrimoniales y no otros aspectos jurídicos de las capitulaciones matrimoniales, como por ejemplo, su interpretación o la liquidación del régimen económico matrimonial pactado. La explicación es sencilla: el art. 9.3 CC sólo regula la validez de los pactos o capitulaciones matrimoniales, por lo que las partes sólo pueden elegir la Ley estatal aplicable a la "validez" de dichos pactos o capitulaciones matrimoniales, pero no la Ley aplicable a otros extremos relativos a tales pactos o capitulaciones matrimoniales; (ii) las partes sólo pueden elegir como Ley aplicable a sus pactos o capitulaciones matrimoniales una de las Leyes recogidas en el art. 9.3 CC: la elección de Ley no es, pues, totalmente libre como sí lo es la elección de la Ley aplicable a los contratos internacionales; (iii) Si la Ley elegida por los cónyuges hace nulos los pactos o capitulaciones matrimoniales pero otra de las Leyes contempladas por el art. 9.3 CC sí que los hace válidos, debe considerarse que dichos pactos o capitulaciones matrimoniales son válidos en virtud de la estructura alternativa de los puntos de conexión del art. $9.3 \mathrm{CC}$. Las partes no pueden alterar la estructura alternativa de los puntos de conexión recogidos en el art. 9.3 CC, precepto claro e imperativo. Estas consideraciones llevan inevitablemente a una transparente conclusión: los acuerdos de elección de Ley aplicable a los pactos o capitulaciones matrimoniales presentan una escasa utilidad práctica. Se limitan a señalar la Ley aplicable, exclusivamente, a la validez de dichos pactos o capitulaciones matrimoniales, sólo pueden recaer en una de las Leyes contempladas por el art. 9.3 CC y, finalmente, en el caso de que la Ley elegida no haga validos los capítulos pero otra de las Leyes a las que se refiere el art. 9.3 CC sí los haga válidos, se aplicará esta otra ley y no la ley elegida.

En tercer lugar, debe recordarse que la capacidad para elegir la Ley aplicable a los pactos o capitulaciones matrimonialesl se rige por la Ley nacional respectiva de cada parte (art. 9.1 CC) y que el consentimiento de las partes debe regirse por la Ley presuntamente elegida, de forma similar a los contratos (art. 10 Reg. Roma I). Ello evita el Forum Shopping. La Ley presuntamente elegida por los cónyuges determinará si el consentimiento ha sido real e informado, sin o con vicios. La Ley aplicable a la forma del pacto de elección de Ley, por último, se determina con arreglo al art. $11 \mathrm{CC}$ y sus puntos de conexión alternativos.

por M. Albaladejo y S. Díaz Alabart, tomo I, vol.II, 2a ed., Ed.Revista de Derecho privado / Edersa, Madrid, 1995, pp. pp. 181-205; ID., "Régimen económico matrimonial (Derecho internacional privado)", en Vv.AA., Enciclopedia jurídica básica, dirigida por A. Montoya Melgar, Ed.Civitas, Madrid, 1995, pp. 5692-5693.

109 J.M. Fontanellas Morell, "Reflexiones sobre el apartado 3 del artículo 9 del Código Civil", en Ma.T. Areces Piñol, Estudios jurídicos sobre persona y familia, Granada, 2008, pp. 355-370.

${ }^{110}$ SAP Barcelona 3 abril 2012 [CENDOJ 08019370122012100279]. 


\section{g) Pactos de elección de Ley aplicable al régimen económico matrimonial}

82. En otras ocasiones, los cónyuges redactan "acuerdos de elección de Ley aplicable" en cuya virtud señalan cuál es la Ley estatal que desean que regule su régimen económico matrimonial. Ejemplo: dos cónyuges franceses con residencia habitual en Madrid redactan un acuerdo en cuya virtud indican que "Convenimos y deseamos que el régimen económico de nuestro matrimonio sea el establecido por la Ley del State de California". Sobre la validez de estos pactos de elección de Ley aplicable al régimen económico matrimonial y a las capitulaciones matrimoniales cabe afirmar lo que sigue.

83. Los arts. $9.2 \mathrm{CC}$ y $9.3 \mathrm{CC}$ no permiten a las partes elegir la Ley aplicable a su régimen económico matrimonial. Tales preceptos sólo permiten: (a) Elegir la Ley aplicable a todos los efectos del matrimonio, lo que incluirá, sin duda, el régimen económico matrimonial pero en ningún caso permiten elegir la ley aplicable, exclusivamente, al régimen económico matrimonial y tal elección sólo es posible entre cónyuges que tenían distinta nacionalidad en el momento de la celebración del matrimonio (b) Elegir la Ley aplicable a los pactos o capitulaciones matrimonialeslas en el marco y con las limitaciones que establece el art. 9.3 CC.

84. El hecho de que la cláusula de elección de Ley aplicable al régimen económico matrimonial sea nula como tal elección de Ley no significa que no pueda surtir otros efectos. En definitiva, esta disposición acordada por los cónyuges es un "pacto o capitulación matrimonial" y puede salvar su validez mediante el art. $9.3 \mathrm{CC}$. En efecto, la validez de esta cláusula debe valorarse a la luz de cualquiera de las leyes a las que remite el precepto citado. Si una de dichas leyes permite a las partes pactar su régimen económico matrimonial a través de unos pactos o capitulaciones matrimoniales que incorporan por referencia el régimen económico matrimonial vigente en un concreto Estado, tales pactos o capitulaciones matrimoniales deben considerarse válidos.

85. Los arts. 9.2 y $9.3 \mathrm{CC}$ se separan con total claridad de numerosos sistemas extranjeros de DIPr. que sí permiten a los cónyuges elegir, directamente, la Ley aplicable a su régimen económico matrimonial, ya sea éste legal o pactado (art. 30.1 Ly de Derecho internacional privado de Italia 1995; art. 15.2 EGBGB; art. 52.1 Leyu federal suizas de Derecho internacional privado de 1987; art. 14.I Ley de Derecho internacional privado de Turquía 1982, así como la jurisprudencia francesa en la materia). En DIPr. español, esta posibilidad no existe.

\section{D) Ámbito de la Ley designada por el art. 9.3 CC}

\section{a) Cuestiones reguladas por la Ley a la que remite el art. $9.3 \mathrm{CC}$}

86. El art. 9.3 CC señala la Ley aplicable a la "validez" de los pactos y capitulaciones matrimoniales. La expresión "validez" presenta un contenido amplio pero dicho contenido no puede ir más allá de la misma expresión "validez". En consecuencia, la Ley designada por el art. 9.3 CC rige estos aspectos jurídicos.

$\left.1^{\circ}\right)$ Elaboración de los pactos y capitulaciones matrimoniales válidos. Desde una perspectiva material, el Derecho estatal designado por el art. 9.3 CC regulará: a) La posibilidad de estipular, modificar o sustituir válidamente los pactos y capitulaciones matrimoniales; $b$ ) El "contenido obligatorio" o régimen imperativo de tales pactos y/o capitulaciones; c) Los acuerdos que los cónyuges pueden alcanzar, es decir, el ámbito de la autonomía material de los cónyuges reconocido por la ley y las cuestiones sobre las que los cónyuges no pueden alcanzar acuerdos en sus pactos o capitulaciones matrimoniales.

$2^{\circ}$ ) Interpretación de los pactos o capitulaciones matrimoniales. El art. 9.3 CC guarda silencio sobre la Ley aplicable a este aspecto. Ahora bien, se trata de una cuestión muy estrechamen- 
te conectada a la validez de estos acuerdos que debe ser resuelta en el contexto de dicho precepto. Por tanto, si los pactos matrimoniales sólo resultan válidos con arreglo a una de las Leyes recogidas en el art. 9.3 CC, dicha Ley debe regir la interpretación de dichos pactos. Otra solución resultaría contraria al favor contractus que inspira el art. 9.3 CC y carecería de toda lógica.

$\left.3^{\circ}\right)$ Liquidación del régimen económico matrimonial. Procede realizar una distinción que combine adecuadamente el art. 9.2 y el art. 9.3 CC para resolver esta espinosa cuestión.

(a) Si los pactos o capitulaciones matrimoniales establecen un entero régimen económico matrimonial elaborado ad hoc por los cónyuges, o bien establecen un entero régimen económico matrimonial por remisión a disposiciones legales concretas que regula el régimen económico matrimonial, la Ley aplicable a la liquidación de dicho régimen económico matrimonial debe ser la Ley estatal que, con arreglo al art. 9.3 CC, considere válidos los pactos. Es la solución más coherente con el art. $9.3 \mathrm{CC}$ : la única Ley que regula la validez de los pactos o capitulaciones matrimoniales debe regir también su liquidación.

(b) Si los pactos o capitulaciones matrimoniales se limitan a modificar o a establecer "aspectos puntuales" del régimen económico matrimonial, la liquidación de dicho régimen económico matrimonial debe realizarse con arreglo a la Ley reguladora de los efectos del matrimonio, determinada con arreglo al art. 9.2 CC.

87. En este sentido, y más en concreto, con arreglo a lo que expone C. Martinez de AguirRe Y AlDAz, la Ley designada por el art. 9.3 CC regulará ${ }^{111}$ : (i) si los cónyuges pueden elegir y hasta qué punto, uno de los regímenes económicos matrimoniales previstos legalmente. Así, en el Derecho de ciertos países escandinavos, no existe una relación concreta de regímenes económicos matrimoniales. Por ello, los cónyuges no pueden elegir entre uno y otro. Deben, por fuerza, limitarse a alterar el régimen económico matrimonial previsto en la Ley, que normalmente es un régimen de comunidad de bienes, para acercarlo lo más posible a un sistema de separación de bienes, indica P. QuinZÁ REDONDO ${ }^{112}$. Por otro lado, el Derecho alemán, griego, italiano, maltés, rumano o polaco sólo permiten a los cónyuges optar por un régimen económico matrimonial de los previstos expresamente en la Ley; (ii) la posibilidad de los cónyuges de introducir alteraciones en los regímenes económicos matrimoniales previstos legalmente; (iii) la posibilidad de los cónyuges de configurar un entero régimen económico matrimonial propio no previsto en la Ley (= diseño ad hoc del régimen económico matrimonial), tal y como permiten el Derecho español, francés, austríaco o portugués; (iv) si los cónyuges pueden adoptar un régimen económico matrimonial propio de un Derecho extranjero o de una unidad territorial no estatal con un ordenamiento jurídico especifico, como Aragón o Baleares; (v) si los cónyuges pueden, simplemente, limitarse a excluir el régimen económico matrimonial previstos legalmente; como régimen general; (vi) si las capitulaciones matrimoniales pueden recoger un inventario de los bienes aportados al matrimonio por los cónyuges y/o por terceras personas; (vii) si las capitulaciones matrimoniales pueden contener en sus disposiciones y hasta qué punto, previsiones patrimoniales que no regulan la economía matrimonial, como donaciones de bienes futuros en caso de fallecimiento, mejoras y promesas de mejorar y otros; (ix) las limitaciones a los pactos capitulares entre los cónyuges. como las constituidas por el régimen matrimonial primario, y las que impone la moral, el orden público, las leyes, las buenas costumbres o el principio de igualdad de derechos entre los cónyuges; (x) si, en el caso de que las capitulaciones matrimoniales vulneren alguno de los límites legales, dichas capitulaciones matrimoniales resultan nulas en su integridad o sólo parcialmente nulas o anulables; (xi) las causas de invalidez de las capitulaciones matrimoniales, y en particular si les son aplicables las reglas de nulidad y anulabilidad propias de los

111 C. Martínez de Aguirre Aldaz, "La economía del matrimonio. Capitulaciones matrimoniales", en C. Martínez de AguiRRE Aldaz y otros, Curso de Derecho Civil (IV) Derecho de Familia, Colex, Madrid, 2007, pp. 197-222. 45-49.

112 P. Quinzá Redondo, Régimen Económico Matrimonial Aspectos Sustantivos y Conflictuales, Tirant, València, 2016, pp. 
contratos, si las capitulaciones matrimoniales pueden anularse o rescindirse por haber sido concluidas en fraude de acreedores; (xii) si es preciso que otros otorgantes de las capitulaciones matrimoniales que no hayan sido los cónyuges, deben intervenir en una eventual modificación de las mismas; (xiii) si para la modificación de las capitulaciones matrimoniales es preciso que haya transcurrido un lapso temporal determinado desde que se acordó el régimen económico matrimonial anterior, o si es necesaria aprobación judicial de dicha modificación, como sucede en ciertos casos contemplados por el Derecho francés y también si pueden modificarse las capitulaciones matrimoniales por vía judicial.

88. En cuanto al orden público internacional español (art. $12.3 \mathrm{CC}$ ), éste operará frente a leyes extranjeras que permitan la conclusión de capitulaciones matrimoniales en las que uno de los cónyuges quede situado en una posición de "desigualdad radical e irrevocable", en expresión de C. MARTINEZ DE AguiRRE y AldAz o aquéllas que permitan pactos o disposiciones que, resulten o no perjudiciales para un cónyuge en mayor o menor grado, le colocan en una situación de desventaja por una mera razón de sexo ${ }^{113}$.

89. Cuando los cónyuges en sus los pactos y capitulaciones matrimoniales, eligen un concreto régimen económico matrimonial recogido sólo en una de las leyes a las que se refiere el art. 9.3 CC, ésa será la Ley que concretará si dicho régimen ha sido correctamente diseñado por los cónyuges y es válido. Si los cónyuges han elegido un régimen económico matrimonial recogido en varias leyes de las mencionadas en el art. 9.3 CC, será aplicable la que haga válido dicho régimen con los menores requisitos legales.

\section{b) Ley aplicable a la interpretación de las capitulaciones matrimoniales y la liquidación del régi- men económico matrimonial y art. $9.3 \mathrm{CC}$}

90. Con arreglo al art. 9.3 CC pueden ser varias las Leyes estatales que consideren "válidos" los pactos o capitulaciones matrimoniales. En dicho caso, surge un agudo problema: ¿Qué concreta Ley estatal de entre las que hacen válidos los pactos o capitulaciones matrimoniales debe regular la liquidación del régimen económico matrimonial íntegramente pactado en capitulaciones matrimoniales y/o la interpretación de las mismas? Varias tesis se han sostenido.

91. Ciertos autores, -es el caso de W. Wengler, P.M. Patocchi y J.M. Fontanellas-, han sostenido una la tesis que podría denominarse "tesis de la jerarquización de conexiones"114. Entienden tales expertos que, en estos supuestos, existe una jerarquía entre las conexiones recogidas en el art. 9.3 CC, pues dicho precepto se integra en el art. 9 CC y en el "estatuto personal", sector que aparece regulado por unos criterios muy claros. De este modo, la Ley que rige los efectos del matrimonio determinada con arreglo al art. 9.2 CC debe prevalecer y deberán observarse las exigencias de forma ad solemnitatem que dicha Ley estatal prescribe. Se trata de una tesis inteligente y bien intencionada, perfectamente expuesta y desarrollada por J.M. FonTANELLAs ${ }^{115}$. Sin embargo, esta lectura puede conducir a resultados paradójicos. En efecto, resulta incoherente e inviable en el caso de que la Ley reguladora de los efectos del matrimonio, determinada con arreglo al art. 9.2 CC, no considere válidas las capitulaciones matrimoniales en el contexto del art. 9.3 CC. En dicho supuesto, resultaría absurdo interpretar unas capitulaciones matrimoniales o liquidar el régimen establecido en las mismas con arreglo a un Derecho estatal que las considera "nulas".

${ }^{113}$ C. Martínez de Aguirre Aldaz, "La economía del matrimonio. Capitulaciones matrimoniales", en C. Martínez de AgulRRE Aldaz y otros, Curso de Derecho Civil (IV) Derecho de Familia, Colex, Madrid, 2007, pp. 197-222.7

114 W. Wengler, "The general principles of Private International Law”, RCADI, 1961, vol.104, pp. 279-469, concr. pp. 354-459; P.M. РАтосCHI, Règles de rattachement localisatrices et regles de rattachement à caractere substantiel (De quelques aspects récents de la diversification de la méthode conflictuelle en Europe), Ginebra, Georg, 1985, pp. 90-92; J.M. FonTANELLAS Morell, "Reflexiones sobre el apartado 3 del artículo 9 del Código Civil", en Ma .T. Areces PiÑol, Estudios jurídicos sobre persona y familia, Granada, 2008, pp. 355-370.

115 Vid. nota anterior. 
92. Otros expertos indican que es más apropiado seguir la tesis de los vínculos más estrechos. Parece más adecuado, en efecto, que las capitulaciones matrimoniales se interpreten con arreglo a una Ley que las considera "válidas" y que el régimen económico fijado por unas capitulaciones matrimoniales se liquide con arreglo a una Ley estatal que también las considera "válidas". En consecuencia, la Ley que debe regir la interpretación de las capitulaciones matrimoniales y la liquidación del régimen capitular, debe ser la "Ley del país más vinculado con la situación matrimonial", siempre que se trate de una Ley estatal designada por el art. 9.3 CC y que con arreglo a la cual, tales acuerdos sean considerados "válidos". Es una solución también seguida en otros países (Sent. Cass. Francia 23 mayo 2006) Esta opción interpretativa se desarrolla correctamente en el contexto del art. 9.3 CC y no en el contexto del art. $11 \mathrm{CC}$. En la órbita del art. $9.3 \mathrm{CC}$, todas las Leyes designadas por tal precepto se hallan en el "mismo nivel" y no existen datos que permitan identificar una Ley más o menos "exigente" a la hora de interpretar las capitulaciones "matrimoniales" o de "liquidar" el régimen económico matrimonial. Por tanto, un razonamiento estrictamente "localizador" en favor de la Ley del país más vinculado con la concreta situación jurídica, permitirá reducir los costes conflictuales en estos casos.

\section{c) Capacidad para otorgar pactos o capitulaciones matrimoniales}

93. La capacidad para estipular capitulaciones matrimoniales se rige por la Ley nacional de cada cónyuge (art. 9.1 CC) (STS 1 julio 1955) ${ }^{117}$. Por tanto, la Ley nacional determinará si el sujeto es capaz o incapaz para otorgar las capitulaciones, y también si es sólo "relativamente incapaz", de modo que puede otorgar las capitulaciones si su capacidad es completada mediante la intervención de otro sujeto, como el padre, tutor, etc. (art. 9.1 CC). La Ley nacional de cada cónyuge indicará si sigue o no el famoso adagio, tan difundido, "habilis ad nuptias, habilis ad pacta nuptialia".

94. En el caso de "incapacidad relativa" del cónyuge, el art. 9.6 CC indica que la Ley de la residencia habitual del sujeto regirá la cuestión de precisar quiénes deben completar el consentimiento del cónyuge, los modos de completar la capacidad y finalmente, las consecuencias, -nulidad o anulabilidad-, de la falta de intervención de estos sujetos.

\section{d) Consentimiento para otorgar pactos o capitulaciones matrimoniales}

95. El consentimiento prestado para otorgar capitulaciones matrimoniales puede estar afectado por vicios: error, dolo, violencia, etc. El DIPr. español carece de norma expresa que designe específicamente la Ley aplicable a esta cuestión. El art. 9.1 CC no parece el precepto aplicable, ya que el consentimiento para otorgar las capitulaciones matrimoniales no es un consentimiento que afecte al "estado civil". Por ello, y ante la laguna, parece más conveniente dar aplicación al art. 9.3 CC, que se refiere a la validez de los "pactos y capitulaciones matrimoniales" en general. En conclusión, la Ley que rige el régimen jurídico de este consentimiento es la Ley que regula la validez de las capitulaciones matrimoniales ex art. 9.3 CC. Esta solución es similar a la que recoge el Reglamento Roma I de 17 junio 2008 sobre la Ley aplicable a las obligaciones contractuales (art. 3.5 y 10 RR-I). La Ley estatal presuntamente elegida por los cónyuges / partes es la Ley que decidirá si el consentimiento de tales sujetos en relación con la Ley elegida, es válido o no lo es.

\footnotetext{
${ }^{116}$ Sentencia de la Cour de Cassation, Chambre civile 1 (Francia), 23 mayo 2006, Bulletin, 2006, I, n. 262 p. 230; https:// beta.legifrance.gouv.fr/juri/id/JURITEXT000007052616.

117 STS 1 julio 1955 [R.2391].
} 


\section{e) Ley aplicable a la forma de los pactos o capitulaciones matrimoniales}

96. Para fijar la ley aplicable a forma de los pactos o capitulaciones es aplicable el art. $11 \mathrm{CC}$ (RDGRN 10 enero 1973) ${ }^{118}$. El art. 11 CC favorece la validez formal de estos acuerdos mediante un sistema de puntos de conexión alternativos. Sobre el art. $11 \mathrm{CC}$ y la validez formal de las capitulaciones cabe precisar varios extremos.

97. Las capitulaciones matrimoniales constituyen un acuerdo de gran impacto práctico en la vida económica de los cónyuges y también de los terceros. Su importancia patrimonial es tan grande que numerosos Estados sólo admiten las capitulaciones matrimoniales otorgadas en documento público o en escritura pública. Esta exigencia formal estricta hace que los cónyuges puedan reflexionar sobre la conveniencia o no de firmar tales capitulaciones matrimoniales y además permiten obtener el consejo del notario antes de su conclusión. La forma solemne notarial se exige en Derecho civil español común (art. 1327 CC), así como en Derecho alemán, austríaco, lituano, francés, belga, entre otros ordenamientos. Pues bien, cuando la Ley estatal que rige la validez de las capitulaciones o pactos, determinada ex art. 9.3 CC, exige una forma jurídica de otorgamiento sin la cual el acto no es válido, -forma ad solemnitatem-, ésta debe ser necesariamente observada. Así lo indica el art. 11.2 CC. Si no es observada dicha forma solemne, entonces el pacto o capitulación será nulo por defecto de forma ad solemnitatem. Varias observaciones resultan útiles: (a) En Derecho civil común español, los arts. 1327 y 1280.3 CC exigen otorgamiento en escritura pública. Si las capitulaciones matrimoniales se rigen, ex art. $9.3 \mathrm{CC}$, por la Ley sustantiva española, pero no se han otorgado en "escritura pública", serán nulas de pleno derecho (vid. con aspectos de Derecho transitorio, STS 20 noviembre 2011 [matrimonio civil contraído por españoles en Méjico en 1940]) ${ }^{119}$; (b) Si las capitulaciones matrimoniales no se rigen por el Derecho español, no es correcto afirmar que se exige la forma solemne a tales capitulaciones bajo pena de nulidad radical de dicho negocio ex art. 1327 CC. Ello dependerá, lógicamente, de la Ley estatal que rija el fondo de dichas capitulaciones según el art. 9.3 CC y no de la Lex Fori (con error: SAP Asturias 6 septiembre 2013 [divorcio entre cónyuges ingleses]) ${ }^{120}$.

98. Cuando las capitulaciones son válidas, en cuanto al fondo, con arreglo a dos o más Derechos estatales de los designados por el art. $9.3 \mathrm{CC}$, ¿cuál es, entonces, la Ley que regula el "fondo" de las capitulaciones, Ley que es preciso determinar a efectos del art. 11.2 CC? Debe prevalecer aquella Ley estatal señalada por el art. 9.3 CC que, haciendo válidas las capitulaciones en cuanto al fondo, exija "menos formalidades" para la validez formal de tales capitulaciones. Esta solución constituye un desarrollo interpretativo del art. 11.2 CC, y no del art. $9.3 \mathrm{CC}$. En consecuencia, dicho desarrollo debe aparecer guiado por el principio del favor validitatis, principio que vertebra el art. $11 \mathrm{CC}$, y no por los principios que constituyen la arquitectura legal del art. 9 CC y del "estatuto personal". Ello implica que resulte plenamente justificado dar aplicación a la Ley estatal que exige requisitos formales más livianos para dar por válidas las capitulaciones matrimoniales. Esta solución es la que ha mantenido de forma brillante la DGRN (RDGRN [5 25 septiembre 2006 [capitulaciones otorgadas por española e italiano ante Notario italiano]).

99. Si los pactos y capitulaciones matrimoniales se otorgan ante autoridad diplomática o consular española, su forma se regirá, necesariamente, por la Ley española (art. 11.3 CC).

100. En cuanto a la publicidad registral de las pactos o capitulaciones matrimoniales en casos internacionales, debe indicarse que la Ley que regula la validez de las capitulaciones ex art. 9.3 CC determina si es necesaria la inscripción de las mismas en algún Registro oficial como "requisito para su validez" (art. 1327 CC) o como "requisito para su oposición a terceros" (art. 77.II LRC). Sin embargo,

\footnotetext{
118 RDGRN 10 enero 1973, Anuario DGRN, p. 421.

${ }^{119}$ STS 20 noviembre 2011 [CENDOJ 28079110012011100831].

${ }^{120}$ SAP Asturias 6 septiembre 2013 [CENDOJ 33044370042013100262].
} 
la Ley del Estado a cuyo cargo se halla el Registro concreta las "modalidades" de la publicidad registral: inscripción, mención, anotación, y efectos de dichas modalidades de acceso a los Registros Públicos. Las capitulaciones matrimoniales inscritas en el Registro de un país extranjero pero no inscritas en España, no son oponibles a terceros de buena fe en el caso de que el Derecho español rija la oposición a terceros de tales capitulaciones matrimoniales.

\section{Reflexiones finales}

101. La entrada en escena del poderoso Reglamento 2016/1103 del Consejo de 24 junio 2016 [regímenes económicos matrimoniales] no debe hacer perder de vista al operador jurídico que este Reglamento no tiene carácter retroactivo. En consecuencia, los efectos, personales y patrimoniales, derivados de los matrimonios celebrados antes del 29 enero 2019 se rigen por la Ley a la que conducen las normas de conflicto de leyes de cada Estado miembro. Ello significa, para España, que los arts. 9.2 y $9.3 \mathrm{CC}$ conservan un ámbito operativo relevante y así será durante muchos años. Por otro lado, ambas disposiciones se aplican en casos de Derecho interregional.

102. El contexto temporal de estos arts. 9.2 y $9.3 \mathrm{CC}$ es relevante. Se trata de preceptos legales que, en su momento, supusieron la constitucionalización plena del sistema matrimonial español de Derecho internacional privado. Sus valores, son, pues, su mayor mérito. Ambos preceptos acabaron con odiosas discriminaciones contra la mujer, contra la selección de la Ley aplicable basada en una inexistente "superioridad legal del varón sobre la mujer". La Ley nacional del marido queda eliminada del sistema y ello es mérito de estas dos disposiciones legales, lo que no es una escasa virtud ${ }^{121}$. En tal sentido, proyectados hacia el futuro, los arts. 9.2 y $9.3 \mathrm{CC}$ seguirán destilando una justicia conflictual plenamente respetuosa con la igualdad de los cónyuges ante la Ley.

103. Desde el punto de vista técnico, los arts. 9.2 y $9.3 \mathrm{CC}$ revelan ciertas carencias en el legislador español. El art. 9.2 CC se presenta como la norma central y unificadora del sistema, como el pivote central del mismo. El art. 9.2 CC trata de concentrar todos los efectos del matrimonio bajo la aplicación de la misma Ley, lo que resulta positivo. Su técnica jurídica es acertada. El precepto proporciona la necesaria seguridad jurídica a la hora de fijar la Ley aplicable a los efectos del matrimonio. Por ello, en palabras de S. DNES, cuando el art. 9.2 CC ha sido aplicado por los tribunales españoles, ha dado lugar a una litigación eficiente, en el que, salvo excepciones muy puntuales, las soluciones relativas a la selección de ala Ley aplicable son claras y estables ${ }^{122}$.

Frente a dicho precepto, el art. 9.3 CC se muestra como un complemento conflictual del art. 9.2 CC y no anduvo ahí tan fino el legislador español de 1990. Se trata de una norma de conflicto con un supuesto de hecho limitado a la "validez" de los pactos y capitulaciones matrimoniales. Una norma que trata de ampliar las posibilidades de concluir unos contratos matrimoniales válidos. Su objetivo es loable, no así su técnica jurídica. El legislador no consideró que los contratos matrimoniales merecieran una norma de conflicto propia y ello complicó la lectura del precepto por los tribunales. El art. 9.3 CC, así, se presenta como un mero complemento del art. 9.2 CC. En momentos en los que la autonomía de los particulares se muestra como el criterio más eficiente en Derecho Privado, los contratos matrimoniales, en su sentido más amplio, carecen de una norma de conflicto propia que indique la Ley aplicable a todo su régimen jurídico. Falla, ahí, tanto la técnica jurídica empleada, la cláusula salvatoria, como el valor que defiende la norma, pues los contratos matrimoniales deberían ser contemplados como el vértice del sistema y no como un complemento de una norma de conflicto con puntos de conexión objetivos fijados al margen de la voluntad de las partes.

${ }^{121}$ J. Meeusen, "Comparing Interstate and European Conflict of Laws from a Constitutional Perspective: Can the United States Inspire the European Union?", American journal of comparative law, 2019-3, pp. 637-676.

${ }^{122}$ S. DNes, “Promoting efficient litigation?", en P. BEAumont ET AL., Cross-border litigation in Europe, Oxford, Hart, 2017, pp. 463-473. 
104. En cuanto al orden de las conexiones retenidas por el art. $9.2 \mathrm{CC}$, todo se ha dicho y se ha escrito. Sumergidos todos en un mundo globalizado que se caracteriza por la liquidez de las relaciones sociales, personales y jurídicas y por la velocidad futurista en las circunstancias de los particulares, el art. 9.2 CC presenta una escalera de conexiones anclada en un pasado manciniano. Demasiado protagonismo para la Ley nacional común, que con cadenas de oro ata a los cónyuges toda la vida para que sea dicha Ley la que rija los efectos de su matrimonio, según ha demostrado A. RodríGuez BenOT ${ }^{123}$.

Poca sensibilidad multicultural refleja el art. 9.2 CC. Como escribe J. SCHACHERREITER, la aplicación de la Ley nacional no es el único modo de mostrar respeto por una cultura jurídica. Es más, puede resultar una condena infinita para ciertas personas cuando resulta muy complicado para las mismas el cambio de nacionalidad y las personas en cuestión se identifican ya más con la Ley del país de acogida ${ }^{124}$. Escaso relieve atribuido a la autonomía de la voluntad conflictual, situada en segundo lugar y sometida a requisitos formalistas. Emergente papel el que corresponde a la Ley de la residencia habitual de los cónyuges tras el matrimonio, pero no suficiente, pues se sitúa como la tercera conexión. Por otro lado, no se tiene en cuenta que la residencia común puede cambiar a otro país y fijarse en el mismo durante largos años. Falta flexibilidad en la conexión para adaptarse a la vida móvil del siglo XXI. El art. 9.2 CC revela ciertas dosis de neo liberalismo conflictual, en la expresión de P. $\mathrm{KINSCH}^{125}$. Sin embargo, le falta el impulso final que haga de los cónyuges los verdaderos protagonistas del diseño legal de sus relaciones jurídicas, le falta un mayor neo liberalismo y eso, en la tercera década del siglo XXI, se revela como una carencia de política jurídica.

De todos modos, con F. JIZENG, cabe recordar que los derechos humanos pueden resultar impulsados y protegidos por las normas de conflicto ${ }^{126}$. En dicho sentido, estos dos preceptos merecen un juicio positivo, ya que, a pesar de ciertas carencias técnicas y valorativas, han contribuido a la movilidad internacional de los cónyuges, a la estabilidad legal de sus relaciones jurídicas a través de las fronteras, a la seguridad jurídica preventiva y a la auto-gestión de sus relaciones jurídicas en casos conectados con distintos Estados.

${ }^{123}$ A. Rodríguez Benot, "El criterio de conexión para determinar la ley personal: un renovado debate en Derecho internacional privado", $C D T, 2010$, vol 2, n. 1, pp. 186-202.

124 J. Schacherreiter, "Das Verhängnis von Ethnozentrismus und Kulturrelativismus in der Rechtsvergleichung - Ursachen, Ausprägungsformen und Strategien zur Überwindung", RabelsZ, 2013.II, pp. 272-299.

${ }^{125}$ P. KINSCH, "Trois visions de l'avenir d'un droit international privé néolibéral", en Liber amicorum Angelo Davi: La vita giuridica internazionale nell'età della globalizzazione, vol. I, Napoli, Editoriale Scientifica, 2019, pp. 165-193.

${ }^{126}$ F. Jizeng, "The Relative Universality of Human Rights: Theory and Practice", Human Rights, n. 2, March 2013 (https:// ssrn.com/abstract $=2593957$ ). 